\title{
MULTINATIONAL CORPORATIONS, OUTSOURCING, AND AMERICAN WAGE DIVERGENCE
}

Matthew J. Slaughter

Working Paper 5253

\section{NATIONAL BUREAU OF ECONOMIC RESEARCH 1050 Massachusetts Avenue \\ Cambridge, MA 02138 \\ September 1995}

\begin{abstract}
A good deal of this work was supported by a National Science Foundation Graduate Fellowship and by the Alfred P. Sloan Foundation through an MIT Industrial Performance Center Dissertation Fellowship. For helpful comments I thank Paul Krugman, Lael Brainard, Robert Z. Lawrence, Andrew Bernard, Ed Leamer, Danny Blanchflower, Gordon Hanson, Jim Hines, Ray Mataloni of the BEA, and seminar participants at RAND, UCLA, the 1995 NBER Labor Studies Summer Institute, and the Dartmouth junior-faculty lunch. This paper is part of NBER's research programs in International Trade and Investment, and Labor Studies. Any opinions expressed are those of the author and not those of the National Bureau of Economic Research.

(C) 1995 by Matthew J. Slaughter. All rights reserved. Short sections of text, not to exceed two paragraphs, may be quoted without explicit permission provided that full credit, including $\odot$ notice, is given to the source.
\end{abstract}




\title{
MULTINATIONAL CORPORATIONS, OUTSOURCING, AND AMERICAN WAGE DIVERGENCE
}

\begin{abstract}
Many economists studying America's wage divergence in the 1980's have concluded that its primary cause was a within-industry shift in relative labor demand toward the more-skilled. Following the modeling framework and empirical methods developed in Slaughter (1993), in this paper I try to determine the extent to which outsourcing by multinational corporations contributed to this labor-demand shift. To do this, I use data from the Bureau of Economic Analysis (BEA) on U.S. manufacturing multinationals in the 1980's. My main finding is that the data are inconsistent with U.S. multinationals having outsourced heavily in the 1980's. First, I construct a set of stylized facts about the employment, investment, and production patterns of these firms. I find that most of these facts are inconsistent with widespread outsourcing. Second, to test more rigorously whether these firms substitute between U.S. and foreign production labor I estimate their factor-price elasticities of demand in a translog-cost-function specification. I find that home and foreign production labor at best seem to be weak price substitutes and in fact may be price complements. Taken together, these findings indicate that multinational outsourcing contributed very little to rising wage inequality.
\end{abstract}

Matthew J. Slaughter

Department of Economics

Dartmouth College

Hanover, NH 03755

and NBER 


\section{Introduction}

'The wages of more-skilled Americans rose sharply in the 1980's relative to those of their lessskilled counterparts. ${ }^{1}$ Many economists studying this wage divergence have concluded that its primary cause was a within-industry shift in relative labor demand toward the more-skilled. ${ }^{2}$

Despite this consensus about the relative-demand shift, however, there is still disagreement about what caused it. Borjas, Freeman, and Katz (1992) and Borjas and Ramey (1993) find that international trade mattered a lot, but Lawrence and Slaughter (1993) and Bhagwati (1995) find that it mattered very little. Freeman (1993) finds that deunionization mattered a lot, but Bound and Johnson (1992) find it mattered very little. Berman, Bound, and Griliches (1994) and Krueger (1993) find that skill-biased technological change mattered a lot, but Mishel and Bernstein (1994) find it mattered very little and Davis (1993) thinks that no one has looked at the right data yet.

In this paper I test another hypothesis for what caused the relative-demand shift. I call it "outsourcing": a variety of foreign direct investment (FDI) by U.S. multinational corporations which shifts less-skilled-labor-intensive activities from the U.S. to foreign countries primarily to arbitrage international wage differentials. In Europe, outsourcing is often called "delocalization." There are at least three reasons to look at outsourcing.

First, several economists--Katz and Murphy, Krugman, and others--have conjectured that outsourcing mattered. ${ }^{3}$ In theory, outsourcing can explain the within-industry demand shifts that actually occurred. As I will show in a general-equilibrium model of multinationals, arbitraging international factor-price differentials by moving production stages across countries can lead to within-industry demand shifts. These shifts can be observationally equivalent to shifts caused by

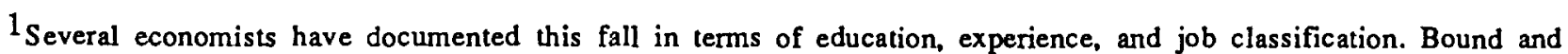
Johnson (1992) find that between 1979 and 1988, the ratio of the average wage of a college graduate to the average wage of a high school graduate rose by 15 percent. Davis (1992) finds that between 1979 and 1987, the ratio of weekly eamings of males in their forties to weekly earnings of males in their twenties rose by 25 percent. Finally, Lawrence and Slaughter (1993) find that in manufacturing between 1979 and 1989, the ratio of average annual wages of non-production workers to average annual wages of production workers rose by nearly 10 percent, from 1.52 to 1.65 .

${ }^{2} \mathrm{Katz}$ and Murphy (1992) conclude "that rapid secular growth in the relative demand for 'more-skilled' workers is a key component of any consistent explanation for rising inequality and changes in the wage structure over the last 25 years." Berman, Bound, and Griliches (1994) calculate that in manufacturing, nearly two-thirds of the overall demand shift was caused by within- rather than between-industry components.

${ }^{3} \mathrm{Katz}$ and Murphy (1992, p. 54) write "Important sources of within-industry shifts [in relative labor demand] include ... 'outsourcing' (shifts of portions of industry production out of the United States)." Krugman (1995, pp. 334,336) writes "It is generally believed that the trend in manufacturing (post-1970) has been to slice up the value chain ... What has happened is that it has proved possible to find expanded niches for labor-intensive production by slicing up the production of goods traditionally viewed as skill-, capital-, or technology-intensive and putting the labor-intensive slices in low-wage locations." Discussants on Lawrence and Slaughter (1993, p. 221) are quoted thus: "Several participants ... argued that some portion of apparent technological change in the United States is driven by the globalization of production, as lowskilled, labor-intensive manufacturing tasks gradually move from the United States to low-wage countries, such as Mexico, while the most skill-intensive jobs continue to be performed in the United States. This globalization of production, therefore, reduces the relative demand for unskilled workers in the United States." Finally, Bluestone and Harrison (1982, p. 170) claim that "large corporations ... can build, expand, or acquire facilities outside the [United States] altogether. In fact, all the strategic innovations devised by multiplant companies for playing off one group of workers against another ... have become standard operating procedure in the global economy."
} 
skill-biased technological change. Thus, the reason that evidence supporting the technology hypothesis has been inconclusive may be that outsourcing, not technology, was shifting demand.

Second, to support these conjectures there is a good deal of anecdotal evidence. For example, a 1986 Business Week special report finds so many cases of multinational outsourcing during the 1980 's that it portends (1986, p. 60) the rise of "hollow corporations" in America. "By shifting production overseas, U.S. companies are whittling away at the critical mass essential to a strong industrial base. If globalization of industry means that U.S. manufacturers will wind up simply licking the labels and sticking them on products that are made abroad, the nation can look forward to a declining standard of living."

Third, very little work has systematically studied how widespread these anecdotes were. Baldwin's (1995, p.55) survey of the effects of trade and FDI on labor markets finds that "there do not seem to be any studies of how the shifts in the pattern of U.S. direct investment and direct foreign investment in the United States have affected relative wages." This overstates the case a bit: a few papers have looked at outsourcing. But their results are mixed, and none of them focuses on multinationals over the entire 1980's.

In this paper I try to determine the extent to which outsourcing contributed to America's labordemand shift and resulting relative-wage divergence. To do this I follow the modeling framework and empirical techniques developed in Slaughter (1993). I first present a general-equilibrium model of outsourcing which is consistent with the stylized facts of U.S. wage inequality in the 1980 's. One of the primary implications of this model is that U.S. multinationals regard U.S. and foreign less-skilled labor as price substitutes. I then test this model using data from the Bureau of Economic Analysis (BEA) on U.S. manufacturing multinationals in the 1980's. These data distinguish non-production from production workers with the definition used in the Census of Manufactures and elsewhere. Following Berman, Bound, and Griliches (1994) and others, I assume that non-production workers represent more-skilled workers and that production workers represent less-skilled workers. This classification is obviously not perfect, but Berman, Bound, and Griliches (1994) argue that it tracks better measures of skill quite closely. If one considers this classification to be too imperfect, then the analysis still provides evidence on the demand shift towards non-production workers that occurred in U.S. manufacturing in the 1980's.

My main finding is that the data are inconsistent with U.S. multinationals having outsourced heavily in the 1980's. First, I construct a set of stylized facts about the employment, investment, and production patterns of these firms. I find that most of these facts are inconsistent with widespread outsourcing. For example, multinationals employed abroad fewer production workers in both absolute and relative terms at the end of the decade than at the beginning. Second, to test more rigorously whether these firms substitute between U.S. and foreign production labor I estimate their factor-price elasticities of demand in a translog-cost-function specification. I find that 
home and foreign production labor at best seem to be weak price substitutes and in fact may be price complements. Taken together, these findings indicate that outsourcing contributed very little to rising wage inequality.

The paper is organized as follows. Section 2 discusses my definition of outsourcing and surveys the literature. Section 3 presents a simple model of outsourcing in which multinational firms arbitrage international factor-price differentials and thereby shift relative labor demands within industries. Section 4 describes the BEA data and presents the set of stylized facts. Section 5 presents the econometric estimates of cost functions from the BEA data. Section 6 concludes.

\section{Definition and Literature Survey of Outsourcing}

\section{Definition}

There are two caveats about what my definition of outsourcing does not cover. First, I do not consider the possibility that multinationals contribute to wage inequality through threatened (rather than actual) relocation abroad. In principle, multinationals might affect U.S. wages by merely threatening to outsource.

Second, I do not consider the "Nike" model of arm's-length outsourcing. In the U.S. Nike employs about 2500 people for firm-wide services like advertising, finance, and R\&D. Abroad about 75,000 people produce Nike shoes, primarily in low-wage countries in southeast Asia. But very few of these 75,000 people work for Nike: the large majority work arm's length in separate firms which Nike contracts to produce its shoes. Like firms which outsource according to my definition, firms like Nike seem to relocate activity abroad primarily to arbitrage lower factor prices there. But what distinguishes the two sets of firms is that I define outsourcing to include only intra-firm activity. Thus, I focus only on companies which decide to internalize transactions because of a market failure.

I define outsourcing this way entirely because of data limitations: the BEA data cover only multinational activity, not arm's-length activity. I do not know how serious this omission is. Oman (1989) provides evidence that the importance of arm's-length activity varies across industries--in particular, it is high in textiles but low in electronics. This seems plausible: a shirt design is no big secret, but the Pentium-chip design is. Nevertheless, all industries in the BEA data have multinationals, and the extent of their outsourcing may very well parallel the extent of arm's-length activity as well. In fact, it can be argued that multinationals have competitive advantages (like easier access to information and capital) which make them more likely to relocate activity abroad. To the extent this is true, multinationals are the better group on which to test the outsourcing hypothesis.

\section{Literature Survey}

The few papers that have addressed outsourcing can be split into two groups. One group looks at trends over time, but primarily at data on U.S. imports rather than U.S. multinationals per se. 
The other group looks at data on multinationals, but only at individual years. The conclusions about outsourcing are mixed.

The first set includes Berman, Bound, and Griliches (1993). They found in the 1987 Census of Manufactures that of the $\$ 104$ billion in imported materials purchased by U.S. establishments, only $7 \%$ originated from the same 3 -digit industry as the establishment itself. They conclude from this small percentage that a negligible amount of outsourcing occurred. Sachs and Shatz (1994) find that the share of multinational-mediated imports from developing countries rose between 1977 and 1990 from $7.1 \%$ to $13.3 \%$. They consider this result to be "very suggestive of the idea that foreign-based production in low-wage countries is used as an export platform for reexport to the US." Feenstra and Hanson (1995) use a panel of 450 4-digit SIC manufacturing industries to regress the annual change in non-production-workers' share of each industry's wage bill on time dummies, changes in industry output and industry capital, and changes in industry imports as a share of total industry shipments plus imports. This measure of outsourcing accounts for $15-33 \%$ of the overall increase in the share of non-production labor in industry wage bills.

These results are very interesting, but one possible problem with them is that the mapping between outsourcing and imports is unclear. Outsourcing may or may not entail increased imports and vice versa. For example, suppose a firm exports widgets to Mexico. If it outsources widget assembly to Chile, it may decide to send the widgets to Mexico directly from Chile. In this case, outsourcing would not show up in the U.S. data as higher imports. It would show up as lower exports. As another example, suppose a country is at full employment and decides to consume more than output by running a current-account deficit. In this case higher imports do not imply outsourcing.

The second set of papers includes Lipsey, Kravis, and Roldan (1982), who for a cross section of U.S. multinationals in 1966 find that higher wages in affiliates are associated with higher capital-labor ratios employed in these affiliates. Kravis and Lipsey (1988) generate two main results from the 1982 BEA data. First, they find that greater affiliate "activity," as proxied by sales, lowers parent employment: a $\$ 1$ million increase in majority-owned-affiliate sales leads to 38 (96) fewer jobs in parents in manufacturing (services). Second, they proxy the skill mix of parent employment with parent compensation per employee to test whether affiliate activity raises the skill intensity of parent production. They find weaker evidence here: for some industries the coefficient on affiliate sales is positive but usually statistically insignificant. Lipsey (1994) repeats these tests on 1988 BEA data and finds the same basic results. Finally, Wheeler and Mody (1992) find that between 1982 and 1988 low foreign labor costs were one of the few statistically significant explanations of observed FDI by U.S. manufacturing multinationals.

These results are also very interesting. They indicate that U.S. multinationals do locate production-labor-intensive activities abroad and that they do choose factor mixes based on factor 
prices--results consistent with the outsourcing hypothesis. But because these studies use only one year of data it is not clear how they can address outsourcing over the entire 1980's. Also, as both Kravis and Lipsey (1988) and Kravis (1994) acknowledge, their results may suffer endogeneity problems by not treating labor at home and abroad as jointly determined.

My work tries to address these issues by using several years of data on multinationals and by estimating cost-minimization functions which treat all factors of production as jointly chosen.

\section{The Theory of Outsourcing}

I present a simple general-equilibrium model of outsourcing which broadly follows the model in Helpman (1984). This is a standard framework in which multinationals emerge to arbitrage international factor-price differentials that trade among domestic firms alone cannot eliminate. For simplicity, the model abstracts from other motives for multinational activity. My presentation differs from Helpman (1984) in two important ways. First, I do not assume increasing returns to scale in one industry because they are not necessary to generate the desired labor-market effects. Second, I analyze more completely the wage and price effects of outsourcing.

The Model

Consider a world with two countries, home and foreign; two industries, computers (C) and textiles (T); and two factors of production, skilled labor (S) and unskilled labor (U). Textiles are produced under constant returns to scale using only unskilled labor according to

(1) $\mathrm{T}=\mathrm{t} \mathrm{U}$,

where $\mathrm{t}>0$ parameterizes textile productivity. ${ }^{4}$ Making computers is a bit more complicated: it combines two distinct activities. One activity is the provision of "headquarters services" $(\mathrm{H})$ such as executive management, finance, advertising, and research and development. Headquarters services are provided under constant returns to scale with just skilled labor according to

$$
\text { (2) } \mathrm{H}=\mathrm{hS} \text {, }
$$

where $\mathrm{h}>0$ parameterizes headquarters productivity. The second manufacturing activity is assembling the computers; it occurs under constant returns to scale with just unskilled labor according to

$$
\text { (3) } \mathrm{A}=\mathrm{aU} \text {, }
$$

where a $>0$ parameterizes assembly productivity. Computer production combines headquarters services and assembly under constant returns to scale according to

$$
\begin{aligned}
& \text { (4) } \quad \mathrm{C}=\mathrm{cH}^{\mathrm{d}} \mathrm{A}^{(1-\mathrm{d})} \\
& =e S^{\mathrm{d}} \mathrm{U}^{(1-\mathrm{d})}, \mathrm{e} \equiv \mathrm{h}^{\mathrm{d}_{\mathrm{a}}(1-\mathrm{d})} \mathrm{c}>0 \text { and } \mathrm{d} \in(0,1) .
\end{aligned}
$$

The dual cost functions of the production technology in (1) and (4) are (5) and (6), respectively.

\footnotetext{
${ }^{4}$ No results in the model depend on the assumption that textile production uses only unskilled labor. I make the assumption purely to simplify things.
} 


$$
c^{c}\left(w_{s}, w_{u}, C\right)=K_{w_{s}}{ }^{d_{w}}{ }^{(1-d)} C
$$

In (5) and (6), $w_{S}$ is the skilled wage, $w_{u}$ is the unskilled wage, and $K \equiv(1-d)^{(d-1)} d^{(-d)} / e$. Preferences are the same in both countries and are homothetic. Without loss of generality, I assume Cobb-Douglas utility:

$$
\text { (7) } U(B, F)=B_{F} g^{(1-g)} \text {, where } g \in(0,1) \text {. }
$$

Finally, each country is endowed with both skilled and unskilled labor: $S_{h}$ and $U_{h}$ for home, $S_{f}$ and $\mathrm{U}_{\mathrm{f}}$ for foreign.

Now divide the world into home and foreign. First, consider the equilibria which obtain under free trade but no multinationals. The Helpman-Krugman (1985) parallelogram diagram in figure 1 helps distinguish the two sets of equilibria. One consists of endowments lying inside the parallelogram, such as point $A$. The other consists of endowments lying outside the parallelogram, such as point $B$.

For endowments inside the parallelogram trade replicates the integrated equilibrium. In particular, it achieves factor-price equalization (FPE), with relative wages in both countries equal to the relative wages of the integrated equilibrium:

$$
\left(\mathrm{w}_{\mathrm{S}} / \mathrm{w}_{\mathrm{u}}\right)_{\mathrm{h}}=\left(\mathrm{w}_{\mathrm{s}} / \mathrm{w}_{\mathrm{u}}\right)_{\mathrm{f}}=\left(\mathrm{w}_{\mathrm{s}}^{*} / \mathrm{w}_{\mathrm{u}}^{*}\right) \text {. }
$$

At $\mathrm{A}$, both countries produce both goods. Home is well endowed in skilled labor relative to foreign, so home exports some computers to foreign in exchange for some textiles. (See Appendix A for the analytic solution to this equilibrium.)

For endowments outside the parallelogram trade cannot replicate the integrated equilibrium. At B home is so well endowed with skilled labor relative to foreign that it has too much skilled labor to employ all its endowment using the integrated-equilibrium production techniques. As a result, home makes only computers using a more skilled-labor-intensive production technique than used in the integrated equilibrium. Foreign makes both computers and textiles and exports some textiles to home in exchange for more computers. Intuition makes clear that in equilibrium:

$$
\left(\mathrm{w}_{\mathrm{sh}} / \mathrm{w}_{\mathrm{uh}}\right)<\left(\mathrm{w}_{\mathrm{s}}^{*} / \mathrm{w}_{\mathrm{h}}{ }^{*}\right)<\left(\mathrm{w}_{\mathrm{sf}} / \mathrm{w}_{\mathrm{uf}}\right) \text {. }
$$

The wage of skilled labor relative to unskilled labor is lower in skilled-rich home than it is in the integrated equilibrium, and it is higher in unskilled-rich foreign than it is in the integrated equilibrium. (See Appendix A for the analytic solution to this equilibrium.)

Thus two types of equilibria obtain in a world with trade but no multinationals. For sufficiently similar endowments, trade achieves FPE. For sufficiently dissimilar endowments, the wage of skilled labor relative to unskilled labor is lower in the skilled-rich country.

Now introduce multinationals into the world. Following Helpman (1984), I do this by giving headquarters services a special feature: for each firm, its services need not be located in the same 
country as the unskilled labor with which they are combined in equation (4). In many industries, inputs such as those listed as examples of headquarters services seem to have this feature. In computer manufacturing, for example, it seems unlikely that the chief financial officer must work in the same country as those who assemble the keyboard. Firm-specific assets such as brand names or entrepreneurial culture often have this feature as well.

With this new production structure, computer firms have an incentive to become multinational when relative wages differ across countries. They will want to outsource: i.e., to locate their headquarters services in the country with the lower skilled-labor wage, and assembly affiliates in the country with the lower unskilled-labor wage. In home, relative demand for labor in the computer industry shifts towards skilled labor. In foreign, it shifts towards unskilled labor. Within each country, then, the desire to outsource changes the within-industry relative demand. This changes each country's overall relative demand and thereby changes each country's relative wages. Thus, outsourcing expands the FPE set that was attainable through trade alone.

The parallelogram diagram in Figure 2 shows this. With multinationals the production rays for computers are no longer $\mathrm{O}_{\mathrm{h}} \mathrm{Q}$ and $\mathrm{O}_{\mathrm{f}} \mathrm{Q}^{\prime}$, which assume that the skilled and unskilled labor making computers must be located in the same country. Because multinationals can separate computer production into its headquarters and assembly components the effective production ray splits into two rays: one for headquarters and one for assembly. Given the assumptions about headquarters and assembly technology in equations (2) and (3), these rays lie on the edge of the diagram's box. With outsourcing, then, the world's effective FPE set expands to include all endowments. 5

Figure 2 reconsiders endowments $A$ and $B$ in this world where multinationals can emerge. At endowments such as A trade alone achieves FPE so no multinationals emerge. But multinationals do emerge at endowments such as B. Computer producers want to locate headquarters in home and assembly in foreign. This increases the demand for skilled labor in home and reduces it in foreign, and it increases the demand for unskilled labor in foreign and reduces it in home. The equilibrium production point which emerges is point $\mathrm{B}^{\prime}$. Here, home is again involved in only computers, as it was at point B without multinationals. But now home's endowment of skilled labor, $\mathrm{OS}_{\mathrm{h}}$, can be combined with foreign unskilled labor. Home-based multinationals therefore combine $\mathrm{OS}_{\mathrm{h}}$ with $\mathrm{S}_{\mathrm{h}} \mathrm{B}$ unskilled labor located in home and with BB' unskilled labor located in foreign affiliates. Foreign continues to make all the world's textiles, and it devotes $\mathrm{O}_{\mathrm{f}} \mathrm{Q}$ unskilled labor to food. $\mathrm{QB}$ unskilled labor remains to assemble computers. Of this $\mathrm{QB}, \mathrm{BB}$ ' work for home-owned affiliates;

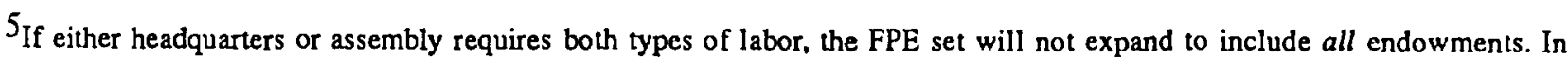
this case, for some endowments multinationals will emerge but will not alter factor demands in each country sufficiently to generate FPE. Helpman (1984) clarifies the possible outcomes. However, in all these cases multinationals do change relative factor demands within countries. I therefore chose the extreme technologies without loss of generality to explain the effect of multinationals as clearly as possible.
} 
the remaining B'Q unskilled labor combines with foreign's entire skilled-labor endowment of $S_{h} Z$ to assemble computers for foreign firms. ${ }^{6}$

Trade flows are more complicated in this equilibrium. Multinationals have created a new tradable good, headquarters services. Home exports these services intrafirm from the headquarters, at a price $\mathrm{w}_{\mathrm{s}}{ }^{*}$, to the foreign affiliates which combine the services with assembly to produce computers. Foreign then exports both computers and textiles back to home; overall, trade remains balanced.

To flesh out how multinationals change the equilibrium for endowments such as B, I present a numerical example. Parameterize the model with the following assumptions: $a=h=c=e=t=1$; $\mathrm{d}=\mathrm{g}=3 / 4 ; \mathrm{S}_{\mathrm{h}}=\mathrm{U}_{\mathrm{f}}=9$; and $\mathrm{U}_{\mathrm{h}}=\mathrm{S}_{\mathrm{f}}=1$. With the analytic solutions given in Appendix $\mathrm{A}$, I can now compare the equilibrium at $B$ without multinationals to the equilibrium at $B$ with multinationals. Table 1 highlights four important differences between the equilibria. First, multinationals equalize relative wages across countries at a level that is both less than relative wages in foreign without multinationals and more than relative wages in home without multinationals. These wage shifts are driven by the demand shifts within the computer industry in each country. Second, multinationals employ some assembly labor abroad. Employment in foreign affiliates of home-headquartered computer firms rises from zero to 2.86 when multinationals emerge. Third, this ability to outsource computer assembly lowers the international price of computers relative to textiles. Fourth, outsourcing increases trade flows by creating a new tradable product: headquarters services. Home-based multinationals export intrafirm 6.67 units of services to their foreign affiliates.

\section{Related Models of Outsourcing}

This model formalizes outsourcing very simply. Multinationals are motivated only by factorprice differentials, and as a result they are vertically integrated (i.e., they locate different production stages in different countries) trading headquarter services intra-firm. This basic model can be extended in a number of ways which still generate the result that outsourcing shifts factor demands within industries. I briefly consider two extensions: richer production structures for vertically integrated firms and additional motives for becoming multinational.

First, consider richer models of vertically integrated firms. Helpman and Krugman (1985) introduce intermediate inputs into production. Factor-price differentials still induce outsourcing, and the new trade flows now include visible trade in intermediate inputs in addition to invisible

\footnotetext{
${ }^{6}$ Actually, at B' several multinational configurations are possible because which country's firms employ which country's skilled labor is indeterminate. For example, some of $O_{h} S_{h}$ may work for foreign-owned multinationals and some of $S_{h} Z$ may work for home-owned multinationals. Here, there would be two-way rather than one-way penetration of multinationals. Following Helpman (1984). I choose the configuration which involves the least amount of multinational activity: all headquarters continue to employ domestic labor, and some home computer firms employ foreign unskilled labor. This choice can be justified as a long-run equilibrium of an adjustment process which involves a cost to shifting facilities abroad.
} 
trade in headquarter services. Feenstra and Hanson (1995) replace a discrete number of production stagès with a continuum of production stages; they also model capital flows explicitly rather than implicitly as flowing from north to south to arbitrage lower capital rental rates in the south. In these extensions outsourcing generates in home the same within-industry effects as in the basic model. Similarly, in these extensions outsourcing generates some form of increased affiliate activity: higher production-employment levels in my model or higher capital-stock levels in Feenstra and Hanson.

The second extension is additional motives for becoming multinational. These include trade barriers (both existing and threatened), transportation costs, communication and monitoring costs, taxes, and political risk. Models of these motives find that in some cases firms decide to expand horizontally rather than vertically (i.e., they located the same production stages in different countries). For example, if trade barriers abroad are high enough the only profitable way for a firm to service that foreign market may be to produce the entire product there. To focus more clearly on the factor-market effects of outsourcing I did not model these additional factors. In reality, though, they must matter to some degree: in my model multinationals instantly and completely arbitrage away international factor-price differentials, but the real world has both multinationals and factor-price differentials. Markusen (1995) surveys models which incorporate these other considerations. These more-realistic models involve more-complicated relationships between multinationals and home labor markets. Foreign expansion need not imply domestic reduction, and as home firms expand into foreign foreign firms may expand into home as well. But the expansion of home multinationals in and of itself may still generate the within-industry demand shifts as in models with vertically integrated multinationals. Moreover, the papers cited in section 2 which have studied multinationals all find evidence that international factor prices play a major role among the various influences on multinationals.

\section{Outsourcing and Trade}

It is worth distinguishing outsourcing from basic international trade. As I have modeled outsourcing, the two differ in at least three important ways. First, outsourcing operates within existing industry classifications rather than across them. It creates new traded goods within industries--in effect, it refines comparative advantage more finely than existing industry classifications. In trade theory without multinationals, trade affects factor demands through the Stolper-Samuelson process mainly by reallocating resources across industries. Second, outsourcing requires multinational firms to exist; trade doesn't. Economists including Lawrence and Slaughter (1993) and Bhagwati (1994) who have studied whether trade affected U.S. wages do not consider the role of multinationals. Third, policies to limit outsourcing and trade would use very different tools. Outsourcing would involve FDI controls but trade would involve tariffs, quotas, and the like. 


\section{Empirical Plan}

I' look for evidence of outsourcing in its labor-market effects. ${ }^{7}$ To reiterate, in my model outsourcing has four main effects. It shifts relative factor demands and thus relative factor prices within countries; it generates unskilled employment abroad within affiliates of multinationals; it creates new tradable goods; and it lowers the relative price of goods made via outsourcing.

My empirical work focuses on the labor-market effects of outsourcing because these data seem to be the most reliable. Very disaggregated trade data does exist, so in principle "newly traded" goods could be identified either as goods whose classification did not exist before 1979 or as goods whose trade increased, all else equal. But as discussed in section 2, distinguishing new trade flows caused by outsourcing from new trade flows caused by other factors (such as preferences) would be difficult. Among other things, it would require detailed knowledge about what sub-industries had been outsourced. Similarly, testing for outsourcing with goods prices would be difficult because America's terms-of-trade data are almost certainly too aggregated to yield any information about outsourcing. The most disaggregated data available are at the two-digit and three-digit SIC level, and it is not clear how price changes caused by outsourcing at lower levels of aggregation would change prices at this level. Given these considerations, my empirical work focuses on the labor market.

\section{Stylized Facts from the BEA Data}

\section{The Data}

Appendix B describes in detail the BEA data. Here, I summarize important aspects of the data.

The BEA tracks U.S. multinationals, each of which consists of one American "parent" and one or more foreign "affiliates." A parent is an individual or a group such as a trust, corporation, or partnership which controls a business enterprise that is incorporated in the U.S. A foreign affiliate is a business enterprise located abroad in which there exists "outward foreign direct investment (FDI)." In turn, outward FDI is defined as direct or indirect ownership or control by a single parent of at least $10 \%$ of either the voting securities of an incorporated foreign business enterprise or an equivalent interest in an unincorporated foreign business enterprise. Majority-owned affiliates are those in which the parent has at least a 50\% ownership stake; minority-owned ones are those in which the parent has a $10 \%$ to $50 \%$ ownership stake.

U.S. multinationals are required by law to provide the BEA with the data it requests. In 1977, 1982, and 1989 the BEA conducted censuses of every American multinational. Between 1983 and

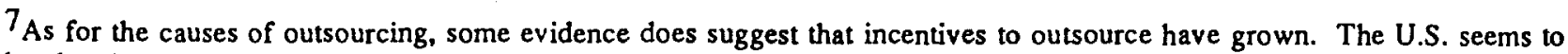
be abundant in skilled labor relative to most countries, which implies that the U.S. pays relatively higher wages to the lessskilled. This wage differential with some countries may have widened during the 1980's. Also, many of the costs incurred by being multinational declined during the 1980 's. Advances in telecommunications and the invention of personal computers and fax machines almost certainly lowered monitoring costs. And many foreign countries (such as Mexico after 1985) began courting multinationals with tax incentives and higher-quality infrastructure.
} 
1988 the BEA conducted surveys which sampled a subset of all U.S. multinationals and then estimated universe totals. The censuses are much more comprehensive. In particular, for both affiliates and parents in 1977 and 1982 and for affiliates in 1989 the censuses disaggregate most labor-market variables between non-production and production workers. Following the advice of BEA officials, I estimate this breakdown for 1989 parents as follows. In all three census years parents reported their employment of $R \& D$ personnel. If one assumes that the $1989 \mathrm{R} \& \mathrm{D}$ share of total non-production employment was similar to that of previous years, then one can straightforwardly estimate the total parent non-production employment. Parent production employment is then estimated by subtracting this amount from the reported total employment. I followed this procedure, calculating each industry's 1989 R\&D share of parent non-production employment as the average of this share in 1977 and 1982 (most shares were quite constant these years, at about 2\%). In what follows, then, the employment breakdown for 1989 parents is actually an estimate and should be interpreted as such.

To classify the activity of multinationals the BEA assigns each parent and each affiliate to the three-digit SIC industry that accounts for the largest share of its total activity. Within a multinational, then, the parent and affiliate(s) need not be classified in the same industry. For example, if AT\&T owns an affiliate which builds electronic switches, then this affiliate is placed in its appropriate manufacturing industry rather than in the telecommunications industry. Also note that industry classification is done at the enterprise level, not the establishment level, and that no publicly released classification is done by affiliate or parent size. The BEA classifies affiliates by country as well. Unfortunately, to prevent disclosure of individual firms it reports data grouped both by industry and by country only at very high levels of industry aggregation. So the data I present are either within countries across industries or within industries across countries.

In its publicly released data the BEA is legally obliged to suppress any information which might identify an individual firm. This suppression limits my work in two ways.

First, widespread suppression in the services sector restricts me to primarily the manufacturing sector. This suppression is primarily because there are very few service multinationals in each non-manufacturing industry. For example, the 1989 census reports 1312 parents in manufacturing but only 89 in banking, 205 in FIRE, and 202 in other services. It may also be because the BEA asks for less information from non-manufacturing firms. For example, in the survey years the BEA does not publish information for the banking sector.

This focus on manufacturing should not be too serious a problem. The large majority of anecdotal cases of outsourcing seem to involve manufacturing activity, so if outsourcing is not widespread in manufacturing then it very likely is not widespread economy-wide. Because the BEA classifies each affiliate independently of its parent's industry, the data on manufacturing affiliates capture any outsourced manufacturing regardless of the industry of the parents doing the 
outsourcing. If AT\&T outsources its switches manufacturing, even though the parent data might be suppressed the affiliate data will not be. In most of my empirical work, I assume that manufacturing outsourcing by services parents is negligible. This seems reasonable for most service industries such as banking, FIRE, etc. The section on the data's robustness will further discuss the relevance of services.

Within manufacturing, for its publicly released data the BEA aggregates parents and affiliates into 32 different industries which are listed in table 2. Some are individual three-digit SIC industries; others are the sum of several three-digit industries; and still others are one or even two two-digit SIC industries. In the U.S. these industries together account for slightly more than $80 \%$ of U.S. manufacturing sales and employment. And in the U.S. between 1979 and 1989, 22 of the 32 experienced both rising relative employment and rising relative wages of skilled labor (weighted by 1977 employment, the 32 industries together experienced an average rise in the ratio of nonproduction to production labor employed of $18.4 \%$ ). Thus, wage and employment trends for these industries match the trends observed with other industrial aggregates.

The second limitation is that the BEA publishes much more data for majority-owned affiliates than for all affiliates (i.e., both majority-owned and minority-owned). In many cases, this restricts me to majority-owned affiliates and their parents. This could present a couple of problems. One might be that minority-owned affiliates behave differently from majority-owned ones. For example, if many low-wage countries restrict FDI to minority stakes then ignoring them might miss important labor-intensive activity. The other possible problem is that changes in majorityowned affiliates might reflect shifts in ownership shares rather than in overall affiliate activity.

In practice neither of these problems seems too serious. Over time, minority-owned affiliates account for a stable $20 \%-25 \%$ of all affiliate activity in terms of sales and employment. For lowwage countries this percentage is not uniformly higher: it is for some countries like Mexico, South Korea, and Thailand but isn't for countries like South America altogether, Singapore, and Taiwan. Trends in minority-owned affiliates seem to parallel and in some cases exceed trends in their majority-owned counterparts. For example, between 1977 and 1989 total employment fell by nearly $14 \%$ in majority-owned affiliates but by more than $32 \%$ in minority-owned affiliates.

Finally, one question is whether to date the decade of the 1980's from 1977 or 1982. Ideally one might start from 1979 because that year and 1989 were both peaks of the business cycle. I use 1977 because it was closer to 1979's cyclical peak than 1982 was in terms of employment and compensation. ${ }^{8}$ However, most stylized facts do not depend on the starting year.

\footnotetext{
${ }^{8}$ For the $32 \mathrm{BEA}$ industries, in 1979 non-production employment relative to production employment was 0.36 and the nonproduction wage bill relative to the production wage bill was 0.55 . In 1977 these measures were 0.35 and 0.55 , respectively. In 1982 they were 0.44 and 0.68 , respectively.
} 


\section{Stylized Facts}

To test the outsourcing hypothesis I first assembled stylized facts for parents and affiliates in manufacturing. I check whether in the 1980's affiliate employment of production workers increased and also whether other measures of affiliate activity such as capital stock and output increased. I look at affiliates both absolutely and relative to parents and U.S. manufacturing overall to control for firm-wide or manufacturing-wide trends affecting all locations equally.

\section{Numbers of Parents and Affiliates}

Table 3 lists the number of manufacturing parents and affiliates (both majority- and minorityowned) by year. Despite the slight rebound in 1989, the clear trend over the decade is shrinking numbers of both parents and affiliates. This fact is inconsistent with the model presented earlier. There, thanks to constant returns to scale, outsourcing increases the number of both parents and affiliates. However, this fact might be consistent with a model of increasing returns to scale and firm exit and entry. In such a model, outsourcing might manifest itself in fewer firms but greater employment per firm such that overall employment still rises.

\section{Employment}

The first implication of the model to check is higher employment in affiliates: outsourcing raises affiliate employment both absolutely and, perhaps, relative to parent employment. Table 4 documents total manufacturing employment in affiliates, parents, and the U.S. overall. ${ }^{9}$ Manufacturing employment declined everywhere during the 1980 's, including by 525,000 in majority-owned affiliates and 658,000 in all affiliates. In percentage terms the decline was about as large or even larger for affiliates compared with parents. Both these facts seem inconsistent with outsourcing. But it might be the case that the overall decline came from non-production workers as production employment actually rose.

The second implication to check is higher production employment in affiliates: outsourcing raises affiliate production employment both absolutely and relative to parent production employment. Table 5 presents non-production and production employment in the three years for which these data exists. The downsizing of majority-owned affiliates was actually concentrated on production workers: of the overall decline of $525,000,495,000$ were production jobs and only 30,000 were non-production jobs. In parents the overall decline was concentrated even more heavily on production workers: the overall decline of $1,066,000$ came from a loss $2,192,000$ production jobs which swamped an increase of $1,126,000$ non-production jobs. It should be remembered that the employment breakdown for 1989 parents is an estimate. Nevertheless, the numbers seem broadly correct when compared with the changes between 1977 and 1982. For

\footnotetext{
${ }^{9}$ In tables 4 and 5, the overall U.S. data cover only establishments where production actually occurs: they do not include non-production workers employed at auxiliary locations. These data come from the NBER's Trade and Immigration Data Base and Wayne Gray.
} 
both affiliates and U.S. manufacturing overall, the majority of the employment changes between 1977 and 1989 had occurred by 1982. If the pattern was similar for parents, the magnitude of the changes between 1977 and 1982 make the 1989 estimates seem reasonable. Table 6 presents the available data on production-worker hours to check whether the employment numbers are masking a different trend in hours. They do not appear to be: trends in hours seem to match trends in employment quite closely. For example, in affiliates a big decline between 1977 and 1982 was followed by a smaller decline thereafter.

Overall, then, tables 5 and 6 present mixed evidence on production employment. In absolute levels it was definitely declining in affiliates-by nearly $21 \%$ over the decade. But the absolute decline in parents was even larger--nearly $33 \%$ over the decade. As a result, relative production employment in multinationals shifted slightly towards affiliates, from $26 \%$ to $29 \%$.

The third implication of the model to check is a shift in the employment mix of affiliates towards production workers: outsourcing raises the production-worker share of affiliate employment both absolutely and relative to the share in parents. Table 5 makes clear that this was not happening in absolute terms. The large decline in affiliate production employment more than offset the small decline in affiliate non-production employment such that production share of total employment fell from 0.63 in 1977 to 0.58 in 1989 . In relative terms, however, affiliates did become slightly more production-labor intensive than parents. The production share of total employment in parents fell from 0.61 in 1977 to 0.46 in 1982 and, estimated, 0.46 in 1989. Thus, affiliates switched from being roughly as production-labor intensive as parents to being somewhat more so.

The fourth implication to check is the response of affiliate production employment to relative production-labor wages between parents and affiliates. All else equal, if production wages are lower in affiliates then affiliate production employment should rise. Alternatively, if there exists some costs to outsourcing that must be compensated for then given these costs as production wages fall (rise) in affiliates relative to parents, affiliate production employment should rise (fall). Table 7 presents some evidence on this by country. The first three columns document the geographic distribution of the fall in overall affiliate production employment. The decline was spread across almost all major groups of countries: Europe $(-370,700)$, Central and South America excluding Mexico (-75,300), and South-East Asia $(-6,100)$. Within these groups, only five countries raised production employment over the decade: Mexico $(+80,900)$, Malaysia $(+15,600)$, Singapore $(+10,400)$, South Korea $(+3,900)$, and Thailand $(+11,700)$.

The second three columns compares these employment trends with trends in relative compensation. This relative compensation is measured as the average hourly compensation rate paid to production workers by majority-owned manufacturing affiliates in that country divided by the average hourly compensation rate paid by all U.S. parents of all majority-owned affiliates. 
There does not appear to be any strong pattern between compensation and employment. First, compensation levels are everywhere lower in affiliates--indeed, in most developing countries compensation is less than $25 \%$ the U.S. levels. But in only five countries do multinationals seem to be taking advantage of this differential by increasing production employment. Second, the worldwide relative compensation rates between parents and affiliates stayed constant but production employment fell by nearly a half million. This is consistent with the costs of outsourcing increasing over the decade, but as discussed earlier these costs were very likely declining. Some countries such as Mexico do have relative compensation and employment moving in the expected opposite direction. But many others--such as Malaysia, Singapore, and Taiwan-have relative compensation and employment moving in the same direction. In these countries, affiliate labor was becoming relatively more expensive yet more of it was being employed. Thus the evidence here is mixed, at best. There does not appear to be any strong pattern across countries between relative affiliate-parent compensation and affiliate employment.

Table 8 complements table 7 by breaking down the overall employment pattern in affiliates by industry instead of country. The overall drop in production employment was widespread across industries: 22 of the 32 employed fewer production workers in 1989 than in 1977. Similarly, the overall shift in affiliate employment mix toward non-production workers was also widespread: 26 of the 32 had a flat or declining share of production employment in total employment. These mix data are not reported by country in table 7, but of those countries only in Mexico did production employment's share rise.

To summarize, there appear to be four important facts in tables 4 through 8. Affiliate total employment fell in absolute terms; affiliate employment of production workers rose slightly as a share of total multinational production employment but fell markedly in absolute terms; the affiliate employment mix became more production-labor intensive relative to parents but less so in absolute terms; and affiliate production employment was not systematically related to relative affiliate-parent compensation. Taken together, these facts seem inconsistent with the hypothesis of widespread outsourcing.

Investment

It is possible that outsourcing was replacing U.S. production labor with foreign capital instead of foreign production labor. Perhaps foreign governments, eager to encourage capital formation, offered multinationals substantial tax incentives to invest. Or perhaps multinationals undertaking greenfield FDI built capital-intensive affiliates which used the newest production techniques. Assume that all else equal, a firm spreads its investment equally across all locations. Then outsourcing should appear in higher investment rates in affiliates. Feenstra and Hanson (1995) model outsourcing in precisely this way. 
Table 9 documents investment by industry in net property, plant, and equipment (NPPE) for both majority-owned affiliates and their parents. These data are reported at book value, so these data are a reasonable approximation for the real capital stocks (see Lipsey, Kravis, and Roldan (1982) on this point). For all industries together, affiliates' annualized growth rate of NPPE exceeded that of parents by only $0.7 \%$. Over the 1980 's, this differential slightly increased the affiliate share of total multinational capital stock from $27.0 \%$ to $28.5 \%$. By individual industry, 18 of the 32 had higher growth rates in affiliates. Thus, the overall impression is that capital accumulation was only slightly faster in affiliates than in parents. This does not seem to be strong evidence that outsourcing replaced U.S. production jobs with affiliate capital.

\section{Output}

One final trend to look at is output in affiliates and parents. There are at least two reasons to do this. First, it is possible that outsourcing was replacing U.S. production labor with foreign factors of production other than labor and capital--factors such as energy and materials. The BEA does not track these other factors, but if outsourcing was taking this form then affiliate output may have been rising relative to parent output. Second, it is possible that outsourcing was "replacing" U.S. production labor with higher total-factor productivity in affiliates. Because of their geographic and cultural distance from parents, perhaps new affiliates incur initial $x$-inefficiencies. If this is the case, then as affiliates gain efficiency parents may shift production towards them without having to employ any additional inputs.

Table 10 documents output by industry for both majority-owned affiliates and their parents. Output is measured as nominal sales. The BEA does not track value added nor sales-price deflators. Without these deflators real-output growth cannot be measured, but if price deflators by industry grew at roughly the same rate in parents and affiliates then sales growth proxies for realoutput growth. For all industries together, affiliates' annualized growth rate of sales was about $1.9 \%$ higher than the similar growth rate for parents. Over the 1980's, this differential increased the affiliate share of total multinational sales from $20.8 \%$ to $24.7 \%$. By individual industry, 21 of the 32 had higher growth rates in affiliates. Thus, affiliate output seems to have grown faster than parent output did. One caveat, however, is that the BEA does not in any way adjust reported sales for transfer-pricing issues. The rise in affiliate sales relative to parent sales is also consistent with increased incentives for multinationals to shift the reported dollar value of sales to affiliates without any change in real output.

\section{Discussion of Stylized Facts}

Overall, the evidence in tables 3 through 10 does not seem to support the hypothesis of widespread outsourcing during the 1980's. It does not indicate that multinationals were on net substituting large numbers of U.S. production jobs for affiliate production jobs, capital, or output. Instead, the evidence indicates that patterns in input usage by parents were matched by affiliates. 
Over the decade both parents and affiliates increased capital stocks, reduced production employment, and shifted employment mix towards non-production workers. This seems consistent with a common factor--such as "skill-biased" technological change--affecting production patterns firm-wide. In principle, it is possible that multinationals were outsourcing heavily but that technological change and/or other factors dominated this such that overall input usage appears consistent only with technological change happening. But this would likely have required much larger effects of technological change in affiliates than in parents. For example, suppose that outsourcing shifted 500,000 production jobs to affiliates. All else equal, 1989 affiliate production employment would then have been about 2.9 million. To get to the actually observed 1.9 million, technological change would then had to have eliminated one million production jobs--more than $40 \%$ of the initial 2.4 million. In contrast, total U.S. manufacturing production employment fell by only about $10 \%$. These magnitudes seem rather unlikely.

This is not to say that outsourcing did not occur at all. Five countries did increase affiliate production employment in levels, and Mexico increased it both in levels and as a share of total affiliate employment. And three industries did increase production employment in both levels and as a share of total affiliate employment--tobacco, miscellaneous chemicals, and computers and office machinery. The increase in affiliate employment in these industries constituted nonnegligible shares of their total production employment in the United States in 1979: 8.6\% for tobacco, $13.9 \%$ for chemicals, and $21.7 \%$ for computers.

However, these cases seem to be the exception rather than the rule. And the magnitudes involved in these cases seem small compared with the absolute size of the U.S. manufacturing sector. Between 1979 and 19892.3 million production jobs were lost in American manufacturing. But except for Mexico and computers, affiliates in no country or industry gained more than 20,000 production employees. The magnitudes appear even smaller when productivity differentials are considered. If affiliates are more production-labor intensive and/or less technologically advanced than parents, then one affiliate production worker is probably less productive than his/her parental counterpart. Thus even if all 81,400 production employees gained in Mexico came from outsourcing, fewer than 81,400 production jobs were probably lost in the United States in the process. Similarly, the 52,300 production jobs gained in the three industries probably cost far fewer than 52,300 American production jobs.

\section{Robustness of Stylized Facts}

There are at least two possible shortcomings of the data just presented. One is that the focus on manufacturing misses important trends in services; the other is that the BEA data altogether miss important trends in multinational activity.

Table 11 addresses the concern that services multinationals differ substantially from manufacturing multinationals. Like manufacturing, the number of parents and affiliates in services 
declined over the decade--in percentage terms, by even more than in manufacturing. Unlike manufacturing, however, services employment rose markedly in parents and slightly in affiliates. In part this probably reflects the secular shift in the U.S. and elsewhere out of manufacturing. No skill breakdown is available for these employment data. But by industry, the increase of 70,000 affiliate employees came from increases in banking, FIRE, retail trade, transportation, utilities, and miscellaneous services which more than offset decreases in wholesale trade, petroleum, agriculture, and mining.

It seems unlikely that the rise in services affiliate employment indicates widespread outsourcing. First, the increase of 70,000 is small relative to the overall U.S. labor market. Second, many industries likely involve activities which cannot profitably be outsourced. In principle there seems to be no widespread technological barriers to outsourcing in services. But high transportation costs make it unprofitable for lots of industries. For example, no technology barrier prevents outsourcing in haircuts: Hong Kong barbers can fly to New York to cut hair at lower wages than New York barbers. But the high cost of international air travel more than offsets the wage gains to firms. Third, even if many service jobs were outsourced many of them were likely more-skilled jobs rather than less-skilled jobs. For example, the new affiliate employees in banking were probably consultants and investment bankers rather than drive-up tellers. Or consider Banglore, India, which has developed a niche in computer programming. Today several thousand programmers there are employed by multinationals like $3 \mathrm{M}$ and Texas Instruments at a fraction of the cost of programmers in the U.S. Thus, it is possible that any outsourcing in services tends to reduce U.S. wage inequality rather than widen it.

The second possible concern with the BEA data is that they miss a significant portion of multinational activity. For one thing, the BEA might systematically miss some companies such as privately-held firms. Or even though compliance with BEA surveys is required by law, some firms--perhaps those which outsource heavily--might not report truthfully because they do not want to divulge information. If this is the case then the BEA data might not truly capture all U.S. multinationals and thus might be a biased sample.

I have two pieces of evidence which corroborate the BEA data. One, admittedly imperfect, is anecdotal evidence. It is worth pointing out that the stylized facts seem to accord with anecdotal evidence. The most widely cited industry and host country for outsourcing seem to be computers and Mexico. For computers, their commodification and labor-intensive components make them a good candidate for outsourcing. And for Mexico, proximity to the U.S. and recent liberalization (joining GATT and pushing the maquiladora program) make it a good host country. Also, the annual reports of some major companies seem to match the stylized facts. For example, the BEA reports higher affiliate production employment in computers and office products and lower employment in automobiles and automobile parts. Annual reports for IBM indicate a rise in its 
foreign employment from 139,000 in 1977 to 167,000 in 1989 . For GM they indicate a slight decline from 217,000 in 1977 to 216,000 in 1989, and for Ford they indicate a large decline from 240,000 in 1977 to 178,300 in 1989 . Thus, the finding that anecdotal evidence supports the stylized facts makes them seem like the "right" numbers to look at for outsourcing.

The second piece of evidence is tax information collected by the Internal Revenue Service (IRS) on U.S. multinationals. When a U.S. multinational files its annual tax return it must also report information about its majority-owned affiliate corporations known as controlled foreign corporations (CFC's). Each tax year every U.S. parent must file a Form 5471 (formerly Form 2952) for each CFC controlled by that person, i.e., in which it held over $50 \%$ of the CFC stock for an uninterrupted period of 30 days during the CFC's annual accounting period. Unfortunately, Form 5471 asks for mainly tax-related information (earnings, foreign taxes paid, etc.) and does not ask about employment or capital stocks. Also, its coverage does not exactly match that of the BEA surveys. It defines tax years as July through June; it does not track unincorporated foreign affiliates; and it counts each CFC in a chain of control separately rather than as one entity. Despite these differences in the two data sets, they can be compared to check whether the BEA data seem to capture the universe of U.S. multinationals.

In 1980, 1982, and 1984 the IRS published summaries of data gathered on all CFC's. Starting in 1986 it published information for only the 7500 largest CFC's, so these later years cannot be compared with the BEA data. Table 12 lists data from both sources for the first three years (for 1980 I substitute 1977 for the BEA data) for parents and affiliates classified in manufacturing. The items listed are number of parents, number of affiliates, and affiliate sales: these are items which both sources contain. The IRS data cover "active" CFC's which reported some positive level of income or foreign taxes. Although not an exact match, the numbers are quite close in both sources: the BEA counts slightly fewer affiliates but slightly higher sales. And the same trends appear in both sources: the number of affiliates dropped drastically from 1980 to 1982 and then moderately from 1982 to 1984 , and sales increased from 1982 to 1984 . Thus, the similarity of the two data sets makes the coverage of the BEA data seem more reliable.

Overall, the stylized facts look robust. The BEA data for services seem broadly consistent with them, and the BEA data overall seem to capture the universe of all multinationals.

\section{Estimating Elasticities of Demand}

Given the results in section 4, it seems reasonable to test more rigorously the basic assumption of the outsourcing model that U.S. multinationals reduce their demand for U.S. production labor when facing lower-cost production labor abroad.

The most appropriate way to test this assumption seems to be to estimate a cost function for these multinationals. From this function I can estimate their price elasticity of demand between U.S. and foreign production labor. Cost functions treat the choice of all inputs simultaneously, 
and thus are preferable to the specifications used in Lipsey (1994) and Kravis and Lipsey (1988). To do the estimation I follow the techniques presented in Hamermesh (1993). However, this work differs in one large way from the studies cited in Hamermesh's (1993) literature survey on estimating factor demands. All those studies treat firms as national entities, and thus assume that firms choose among only factors located in one country. This assumption does not hold $\mathrm{f} r \mathrm{r}$ multinational firms which, by definition; employ factors in more than one country. For multinationals it seems more appropriate to estimate cost functions which allow firms to choose among both domestic and foreign factors. This is the approach I take.

\section{Methodology}

Following Hamermesh (1993), define a firm's partial price elasticity of demand for factor $i$ with respect to factor $j$ as

(8) $\quad \eta_{\mathrm{ij}} \equiv \partial \ln \mathrm{X}_{\mathrm{i}} / \partial \ln w_{\mathrm{j}}$,

where $X_{i}$ is the demand for factor $i, w_{j}$ is the price of factor $j$, and output and all other factor prices are held constant. Factors $i$ and $j$ are defined as price substitutes when $\eta_{i j}>0$, and as price complements when $\eta_{\mathrm{ij}}<0$. I formalize the outsourcing hypothesis as follows: multinationals which outsource regard parent and affiliate production labor are price substitutes.

(9) $\mathrm{H}_{\mathrm{o}}: \quad \eta_{\mathrm{pa}} \equiv \partial \ln \mathrm{X}_{\mathrm{p}} / \partial \ln \mathrm{w}_{\mathrm{a}}>0$ and $\eta_{\mathrm{ap}} \equiv \partial \ln \mathrm{X}_{\mathrm{a}} / \partial \ln \mathrm{w}_{\mathrm{p}}>0$,

where demand and prices are for production labor. This hypothesis says that when affiliate (parent) production wages fall, American multinationals demand less parent (affiliate) production labor as they substitute production into the now-cheaper affiliate country (U.S.). The alternative hypothesis is that these factors are price complements.

To get these elasticities I estimate cost-share equations of a translog cost function on a panel of the 32 BEA manufacturing industries over time. I choose a cost function dual of a production function rather than the production function itself because for these industries it seems more reasonable to assume that they face exogenous factor prices and choose factor quantities rather than vice versa. Estimating prices and quantities in a simultaneously determined system is beyond the scope of this paper, and according to Hammermesh (1993) most studies using similar levels of disaggregation estimate cost functions rather than production functions. Also, I choose the translog specification because it does not impose any restrictions on the pairwise elasticities of substitution and thus on the pairwise elasticities of demand. In contrast, a Cobb-Douglas specification restricts all pairwise elasticities of substitution to equal one and a CES specification restricts all of them to equal some constant (not necessarily one). 
The translog cost function can be written as follows.

$$
\begin{aligned}
& \ln C_{a t}=\alpha_{o}+\sum \alpha_{i} \ln P_{i a t}+\frac{1}{2} \sum_{i} \sum_{j} \beta_{i j} \ln P_{i a t} \ln P_{j a t} \\
& +\alpha_{y} \ln Y_{a t}+\frac{1}{2} \beta_{y y}\left(\ln Y_{a t}\right)^{2}+\sum_{i} \beta_{i y} \ln P_{i a t} \ln Y_{a t} \quad 10
\end{aligned}
$$

Here, $C_{a t}$ is total cost in industry a at time $t, P_{i a t}$ is the price of factor $i$ in industry a at time $t$ (with $N$ total factors), $Y_{a t}$ is output in industry a at time $t$, and by symmetry $\beta_{\mathrm{ij}}=\beta_{\mathrm{ji}} \forall(\mathrm{i}, \mathrm{j})$. For multinationals I assume that output is total firm output summed across parents and affiliates. Similarly, I assume that costs are total firm costs in U.S. dollars summed across parents and affiliates. Because these multinationals are headquartered in the U.S., it seems reasonable to assume that their objective is to minimize U.S.-dollar costs, given output (i.e., to maximize U.S.dollar profits). Log-differentiating this function with respect to factor prices gives the following set of $\mathrm{N}$ cost-share equations.

$$
S_{\text {iat }}=\alpha_{i}+\sum_{j} \beta_{i j} \ln P_{j a t}+\beta_{i y} \ln Y_{a t}, \forall i \in N
$$

$S_{i a t}$ is the share of factor $i$ in total cost for industry a at time $t$, with $S_{i a t} \in(0,1)$ and $\sum_{i} S_{i a t}=1$. Each cost function with $\mathrm{N}$ factors, then, implies a system of $\mathrm{N}$ cost-share equations, one for each factor of production. By dropping one of the equations (to retain linear independence among the remaining ones, because $\left.\Sigma_{\mathrm{i}} S_{\text {iat }}=1\right)$ the $(\mathrm{N}-1)$ remaining share equations can be estimated with the cross-equation symmetry restrictions on the $\beta_{\mathrm{ij}}$ 's. Estimates of the $\beta_{\mathrm{ij}}$ 's can then be mapped into estimates of the $\eta_{i j}$ 's as follows:

$$
\eta_{i j}=\frac{\beta_{i j}+S_{i} S_{j}}{S_{i}} \text { and } \eta_{i i}=\frac{\beta_{i i}+S_{i}^{2}-S_{i}}{S_{i}} \text {, }
$$

where $S_{i}$ is the sample average cost share of factor $i$. Anderson and Thursby (1986) derive a method by which confidence intervals for these $\eta_{i j}$ can be calculated to test the null hypothesis. ${ }^{11}$

10 Assumptions about the behavior of this function imply various testable restrictions. Linear homogeneity in prices implies that $\Sigma \alpha_{i}=1, \Sigma_{i} \beta_{i j}=\Sigma_{j} \beta_{i j}=0$, and $\Sigma_{i} \beta_{i y}=0$. Homotheticity implies that $\beta_{i y}=0 \forall i$. Homogeneity of degree $x$ in output implies, in addition to the homotheticity restriction, $\beta_{y y}=0$ and $\alpha_{y}=1 / x$.

11 Anderson and Thursby (1986) demonstrate with Monte Carlo simulations that the elasticity estimators derived from a translog cost function are very likely distributed normally or as a ratio of normals. Moreover, they find that the confidence intervals implied by both distributions are nearly identical. For the normal-distribution case, the X\% confidence interval for some estimated $h_{i j}$ is: $\pm \frac{Z_{X}}{S_{i}} \times\left[N^{-1} h_{i j} s_{i}^{2}-\left(2 r h_{i j} s_{i}\right)\left(N^{-1}\left(s b i j{ }^{2}+v\right)\right)+s b i j{ }^{2}+v\right]^{1 / 2}$. In this expression, $Z_{x}=c r i t i c a l$ value taken from the standard normal distribution for $X \% ; S_{i}=$ sample mean of cost share of factor $i_{i} s_{i}=$ sample standard deviation of cost share of factor $i_{;} N=$ sample size; $r=$ estimated correlation between the numerator and denominator of $h_{i j}$; $s_{b i j}=$ estimated standard error of $b i j ;$ and $v=\frac{s_{i}{ }^{2} s_{j}{ }^{2}+s_{j}{ }^{2} s_{i}{ }^{2}+2 s_{j} s_{j} s_{i} s_{j} r_{i j}+\left(1+r_{i j}\right) s_{i}{ }^{2} s_{j}{ }^{2}}{T}$ with $r_{i j}=$ sample correlation between $S_{i}$ and $S_{j}$. As one might expect, the more precisely one estimates $b_{i j}(i . e .$, the smaller is $s$ bij) the smaller is the confidence level around $h_{i j}$ for any given $\mathrm{Zx}$. However, even if $b_{i j}$ is significantly different from zero at the $X \%$ level of significance, the confidence interval for $h_{i j}$ can still include zero. 
Panel Choice

Unfortunately, data for both parents and affiliates on non-production and production employment is available for only 1977 and 1982; recall that I had to estimate the 1989 parent breakdown. This presents a major problem. At best, a panel with disaggregated employment contains only 96 observations--32 industries over three years. And adding industry and time dummies to (11) to control for cross-industry and cross-time variation leaves barely 50 degrees of freedom. The alternative is to include the survey years to form a panel of 288 observations-- 32 industries over nine years. The tradeoff for tripling the number of observations is losing the nonproduction/production breakdown. Given that the paper focuses largely on this breakdown, this is a major tradeoff. My solution is to estimate both panels and then check if their results agree.

\section{Nine-Year Panel: Specification}

For each industry-year observation the data on parents covers the parents of all affiliates in that industry. Data on affiliates is available for both all affiliates and just majority-owned affiliates. All data are measured in U.S. dollars. Output of the firm is measured as the sum of parent and affiliate sales. In addition, four factors of production need to be measured: parent labor, affiliate labor, parent capital, and affiliate capital.

For both parents and affiliates, labor is total employment of both non-production and production workers and its factor price is measured as total annual compensation per worker. Because the BEA surveys count full-time and part-time workers equally, this compensation measure may understate the true levels of compensation. ${ }^{12}$

Measuring capital is more complicated in two ways. First is the issue of measuring quantities. The most relevant measure of capital as a productive input is probably net property, plant, and equipment (PPE). Unfortunately, net PPE is reported for only majority-owned affiliates. For all affiliates and parents, the only available measure of capital is total assets. This encompasses both non-current assets (such as PPE) and current assets (such as accounts receivable and inventories).

The second issue is measuring prices. The BEA does not keep data on capital rental rates, so I use annual long-term corporate bond rates for all manufacturing as compiled by Moody's Investor Service and reported in the Federal Reserve Bulletin. These rates apply to only capital raised in the U.S., so using them entails the assumption that multinationals face the same capital cost in both parents and affiliates. This may not be too bad an assumption. Most multinationals have the ability to raise capital on international capital markets, so they can source capital internationally at one world price (although they usually must still source labor locally at local labor prices). It still

\footnotetext{
12 To address the concern that the BEA compensation costs are not truly exogenous to the multinationals, I would like to instrument for these costs with some altemative measure of the "market" wage. However, because the affiliate data are aggregated across all countries (and each industry is almost certainly spread across countries differently), I don't know what would be the appropriate instrument wage for affiliates.
} 
may be the case, however, that the Hall-Jorgensen user cost of capital varies across locations than'ks to variation in taxes, etc.

If one does not like this capital-cost measure then parent and affiliate capital can be treated as fixed factors of production, as suggested by Berndt (1991). In this case capital enters (11) as quantities rather than prices. The relevant costs are now variable costs only; the cost function can be thought of as a short-run function for which capital stocks are fixed at levels other than their long-run equilibrium values. In contrast, if capital is treated as a variable input and enters (11) as a price rather than a quantity; the cost function is then a long-run cost function for which all inputs are adjusting to their long-run equilibrium values. Thus, how to account for capital depends on two big issues: how reasonable the capital-price measure is and whether capital is best thought of as a fixed or flexible factor at each point in time.

An issue which potentially affects all regressors is measurement error induced by exchange-rate volatility. As discussed in the appendix, affiliates must convert local-currency sales and compensation into dollars at current market exchange rates. If one thinks that outsourcing decisions depend on not just current but also future affiliate factor prices, then the prices calculated from current exchange rates may not be the correct measure. In this case the reported affiliate compensation costs are noisy regressors which may lead to biased estimates. While measurement error is possible, two considerations make it seem less likely. First, a lot of work in empirical international finance has concluded that the best predictor today of tomorrow's exchange rates is today's exchange rates. Second, in the 1980's many countries--including many low-wage countries such as Hong Kong--pegged their currency to the U.S. dollar. As of 1989, 32 countries worldwide were pegged.

In light of these data considerations I estimated six different specifications.

(S1) All affiliates matched with the parents of all affiliates; affiliate capital measured as assets; both affiliate and parent capital treated as a fixed input.

(S2) All affiliates matched with the parents of all affiliates; affiliate capital measured as net PPE; both affiliate and parent capital treated as a fixed input.

(S3) Majority-owned affiliates matched with the parents of all affiliates; affiliate capital measured as net PPE; both affiliate and parent capital treated as a fixed input.

(S4) Same as (S1), but capital is treated as a variable input.

(S5) Same as (S2), but capital is treated as a variable input.

(S6) Same as (S3), but capital is treated as a variable input.

When capital is treated as a fixed input, the quantities of parent and affiliate capital appear in (11) as separate regressors. The measure of costs is then just total firm compensation shared between parent and affiliate labor. When capital is treated as a variable input, the "world" capital price appears in (11) as one regressor. The measure of costs is then total firm capital costs plus 
total firm labor costs with these costs shared among parent labor, affiliate labor, and firm capital. In áddition to factor prices and quantities, all specifications include as regressors a full set of industry and time dummies. Industry dummies control for cross-industry variation in input mix; time dummies control for trends over time such as technological change which may affect all industries' input mix. Thus, for each specification the set of cost-share equations actually estimated is given by

$$
\text { (11') } S_{i a t}=\alpha_{i}+\sum_{j} \beta_{i j} \ln P_{j a t}+\beta_{i y} \ln Y_{a t}+\gamma D_{a}+\delta D_{t}+\varepsilon_{i a t},
$$

where $D_{a}$ is the set of industry dummies, $D_{t}$ is the set of time dummies, and $\varepsilon_{i a t}$ is the additive error term assumed to be independently and identically distributed.

For robustness I ran each specification with and without output included as a regressor (excluding output is implied by homotheticity of the cost function). In all cases the estimates were very similar either way. I also ran each specification with and without adjusting for suppressed data. For a few observations the BEA suppressed the employment and/or capital levels. ${ }^{13}$ I first ran the regressions without these observations; I then reran the regressions including imputed values of the missing variables, where the imputed values were predictions obtained from regressing employment and then capital on all other regressors. The estimates were very similar either way. For all specifications I used Zellner's SURE (seemingly unrelated regressions) technique to estimate each set of cost-share equations. ${ }^{14}$

\section{Nine-Year Panel: Results}

Table 13 presents the main results for all six specifications, each of which excluded output and dropped missing observations. In this table the subscripts " $a$ " and "p" designate affiliate and parent, respectively. Overall, the results seem reasonable. The $\beta_{\mathrm{pa}}$ s are all significantly different from zero at the $95 \%$ or even $99 \%$ level of confidence. The implied $\eta_{\mathrm{pa}}$ 's also seem to be estimated quite precisely: three of the six have $95 \%$ confidence intervals strictly on one side of zero and two others are nearly so. Also, none of the implied elasticities of demand is outrageously large and all own-price elasticities (except for one) are negative. The results from specifications (S1) through (S3) as a group are very similar to each other; the same is true for specifications (S4) through (S6). This indicates that the results are robust both to whether all affiliates or only majority-owned affiliates are used and to how affiliate capital is measured. This is probably because majority-owned affiliates tend to account for over $75 \%$ of all affiliate activity and because

${ }^{13}$ The observations were from the late $1980^{\circ}$ s and were for farm and garden machinery, miscellaneous machinery. agricultural chemicals, and miscellaneous chemicals.

14 One additional robustness check replaced the overall-industry bond rates with bond rates for AAA-rated firms only, on the assumption that perhaps multinationals on the whole are less-risky firms. The results with this alternative capital-cost measure were basically the same. 
the sample correlation between majority-owned affiliates' net PPE and all affiliates' assets is 0.9405 .

The main result from table 13 is that whether parent and affiliate labor are price complements or price substitutes seems to hinge on whether capital enters the regressions as a fixed input or a variable input. In the first three specifications which treat capital as a fixed input, the two labor groups are estimated to be price substitutes (with $\eta_{\mathrm{pa}}$ estimated to be somewhere between 0.045 and 0.113 ). But in the second three specifications which treat capital as a variable input, the two labor groups are estimated to be price complements (with $\eta_{\mathrm{pa}}$ estimated to be somewhere between -0.040 and -0.139 ). If one assumes that both sets of specifications are reasonable and that all variables are measured correctly, then this result seems consistent with Berndt's (1991) distinction between short-run and long-run cost functions. In the short run where the level of multinational capital is treated as fixed, it makes sense that firms can substitute between only parent and affiliate employment. But in the long run where firms can adjust all inputs, multinationals apparently treat the two labor groups as price complements. Alternatively, one might object to one (or both) set of specifications on measurement grounds. For example, one might think that the bond-rate series are an inadequate measure of capital costs. In this case the other specification is the one to focus on.

Unfortunately, these elasticities do not truly test the hypothesis given in (9) because they do not distinguish between non-production and production employment. The link between these elasticities and elasticities of the labor sub-groups is unclear. But assume for now that these elasticities are close to the true elasticities between these sub-groups. Then these results do not seem to support the outsourcing hypothesis that multinationals treat production labor in parents and affiliates as price substitutes. If one prefers specifications (S4) through (S6) then the hypothesis is rejected. In this case, parent and affiliate production labor appear to be price complements: as affiliate production wages fall, demand for parent production labor actually rises, not falls. Even if one ignores (S4) through (S6), the magnitude of price substitution involved in (S1) through (S3) does not seem large enough for outsourcing to have contributed significantly to the U.S. demand shift away from production labor. The "worst-case" scenario is in (S3), where the $95 \%$ confidence interval for $\eta_{\mathrm{pa}}$ extends to 0.17 . At 0.17 a nearly $6 \%$ drop in affiliate compensation costs, all else equal, is required to lower multinationals' demand for production labor in U.S. parents by only $1 \%$. And according to table 5 , these firms employ only $40 \%-50 \%$ of all U.S. production labor. So large drops in labor costs abroad seem to lead to relatively small drops in overall demand for labor in the U.S. For example, a 20\% drop in affiliate compensation costs leads to only a $1.5 \%$ drop in overall demand for U.S. production labor. Thus, even the "worstcase" estimate of the degree of price substitutability between parent and affiliate labor seems inconsistent with outsourcing having contributed significantly to America's labor demand shift. 


\section{Three-Year Panel: Specification}

'The three-year panel has only 96 observations--32 industries over three years. Moreover, 1989 has only estimates of the non-production/production breakdown for parents. If incorrect, these estimates introduce measurement error into the labor-cost regressors and thus bias estimates. Aware of these two major problems, I nevertheless fit a translog cost function to this panel because it can directly test the outsourcing hypothesis.

In this panel the affiliates are majority-owned affiliates only and the parents are the parents of these affiliates only. As before, all variables are measured in U.S. dollars. Output is measured as the sum of parent and affiliate sales; capital is measured as net PPE. For production labor the BEA measures annual compensation and hourly compensation. Because part-time and full-time employees are counted equally by the BEA, the hourly measure is probably more accurate. For non-production labor the BEA measures only annual compensation. To impute hourly compensation data for these workers, from the NBER Trade and Immigration data set I calculated for each industry-year the average number of hours worked by non-production workers in U.S. establishments. I then assumed that non-production workers in parents and subsidiaries worked this amount of hours and divided the total compensation figure by these hours. Thus, for each labor type I have annual compensation and hourly compensation. The caveat mentioned earlier about measurement error induced by exchange-rate volatility applies here as well.

Given these data, I estimated four different specifications.

(Sp1) Four factors of production--the four labor types; factor prices are annual compensation.

(Sp2) Same as (Sp1), but factor prices are hourly compensation.

(Sp3) Six factors of production--the four labor types plus home and foreign capital; factor prices are annual compensation; home and foreign capital are treated as fixed inputs.

(Sp4) Same as (Sp3), but factor prices are hourly compensation.

$(\mathrm{Sp} 1)$ and (Sp2) assume that the four labor types are separable from capital and all other inputs in the production function, and thus that substitution among labor types does not depend on any other factors. This assumption might seem questionable in light of the empirical evidence of capital-skill complementarity. Nevertheless I estimate it, and in this case costs are measured as total compensation across all labor. (Sp3) and (Sp4) treat capital as a fixed input. As before, this means that the cost function is a short-run function with costs measured as in (Sp1) and (Sp2) and with the quantities of parent and affiliate capital appearing in (11) as separate regressors. I treat capital as fixed because in the nine-year panel, with fixed capital parent and affiliate labor were price substitutes. In addition to factor prices and quantities, all specifications include as regressors a full set of industry and time dummies. For each specification, the set of cost-share equations estimated is again given by (11'). For robustness I ran each specification with and without output 
included as a regressor; in all cases the estimates were very similar either way. No data were suppressed in this panel. All estimates were obtained using Zellner's SURE technique.

\section{Three-Year Panel: Results}

Table 14 reports the main results for all four specifications run excluding output. As before, the subscripts designate parents and affiliates. Comparing ( $\mathrm{Sp} 1)$ with (Sp2) and (Sp3) with (Sp4) indicates that the results do not depend on the compensation measure used. But not surprisingly, the estimates are much less precise than those of the nine-year panel. None of the $\beta_{\mathrm{pa}}$ 's are significantly different from zero, and thus none of the $\eta_{\mathrm{pa}}$ 's have $95 \%$ confidence intervals which exclude zero. Because these intervals include zero, it appears that parent and affiliate production labor may be either price complements or price substitutes. The same is true for most of the other $\eta_{\mathrm{ij}}$ 's. Lack of significance aside, if one is willing to place some value in the point estimates then the results look somewhat reasonable in that seven of the eight own-price elasticities of demand are less than zero. And the point estimates for $\beta_{\mathrm{pa}}$ reject the null hypothesis that production labor in parents and affiliates are price substitutes for multinationals. Instead, the estimates indicate a strong degree of price complementarity: a $1 \%$ drop in affiliate production-labor costs increases parent demand for production labor by $.35 \%$.

\section{Conclusion}

In this paper I have studied whether in the 1980's outsourcing by U.S. multinationals contributed to the shift in U.S. labor demand towards the more-skilled. To do this I followed the modeling framework and empirical techniques developed in Slaughter (1993). In theory, outsourcing can cause within-industry shifts in relative factor demands and thus relative factor prices. But the empirical results indicate that in practice, multinationals in the 1980's were not outsourcing to a large extent. This is the impression from both assembled stylized facts and estimated cost functions. I find that most stylized facts are inconsistent with widespread outsourcing. I also find that home and foreign production labor at best seem to be weak price substitutes and in fact may be price complements. Taken together, these findings indicate U.S. multinationals were not motivated predominantly by international factor-price differentials, and thus that outsourcing contributed very little to rising income inequality.

These results leave unanswered the question of what did cause the shift in labor demand. The similarity between parents and affiliates in their employment and investment trends suggests that "skill-biased" technological change was occurring both in the U.S. and abroad. Additional work is needed to determine whether this was the case--and in particular, whether the technological progress in affiliates consisted of simple $x$-efficiency gains or changes more similar to those in parents. 


\section{Appendix A: Analytic Solutions to the Model}

\section{Endowment A}

For endowment points such as A, five equations can characterize the integrated equilibrium. Equations (A1) and (A2) are zero-profit conditions which set average cost equal to price. $P$ represents the price of a computer, and the price of textiles is normalized to equal one.

$$
\begin{gathered}
\text { (A1) } \mathrm{Kw}_{\mathrm{s}} \mathrm{d}_{\mathrm{w}_{\mathrm{u}}}(1-\mathrm{d})=\mathrm{P} \\
\text { (A2) } \quad \mathrm{w}_{\mathrm{u}} / \mathrm{t}=1
\end{gathered}
$$

Next, equations (A3) and (A4) are factor-market-clearing conditions for skilled and unskilled labor, respectively. World demand for each factor (given by Shephard's lemma) equals world supply.

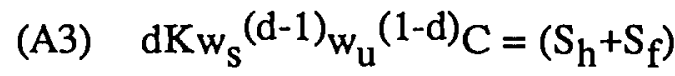

$$
\begin{aligned}
& \text { (A4) } \quad(1-d) \mathrm{Kw}_{\mathrm{s}} \mathrm{d}_{\mathrm{w}_{\mathrm{u}}}(-\mathrm{d}) \mathrm{C}+\mathrm{T} / \mathrm{t}=\left(\mathrm{U}_{\mathrm{h}}+\mathrm{U}_{\mathrm{f}}\right)
\end{aligned}
$$

Finally, equation (A5) is a goods-market-clearing condition which sets expenditure on computers equal to the fraction $g$ of total world income.

$$
\text { (A5) } \quad \mathrm{PC}=\mathrm{g}\left(\mathrm{w}_{\mathrm{u}}\left(\mathrm{U}_{\mathrm{h}}+\mathrm{U}_{\mathrm{f}}\right)+\mathrm{w}_{\mathrm{s}}\left(\mathrm{S}_{\mathrm{h}}+\mathrm{S}_{\mathrm{f}}\right)\right)
$$

The endogenous variables are $w_{u}, w_{s}, P, C$, and $T$. Solving (A1)-(A5) for these variables yields the following equilibrium values.

$$
\begin{aligned}
& \text { (A6) } \mathrm{w}_{\mathrm{u}}{ }^{*}=\mathrm{t} \\
& \text { (A7) } \quad \mathrm{w}_{\mathrm{s}}{ }^{*}=\operatorname{dtg}(1-\mathrm{dg})^{-1}\left(\mathrm{U}_{\mathrm{h}}+\mathrm{U}_{\mathrm{f}}\right)\left(\mathrm{S}_{\mathrm{h}}+\mathrm{S}_{\mathrm{f}}\right)^{-1} \\
& \text { (A8) } \mathrm{P}^{*}=(1-\mathrm{d})^{(\mathrm{d}-1)}(1-\mathrm{dg})^{-\mathrm{d}} \mathrm{e}^{-1} \operatorname{tg}^{\mathrm{d}}\left(\mathrm{S}_{\mathrm{h}}+\mathrm{S}_{\mathrm{f}}\right)^{-\mathrm{d}}\left(\mathrm{U}_{\mathrm{h}}+\mathrm{U}_{\mathrm{f}}\right)^{\mathrm{d}} \\
& \text { (A9) } \\
& C^{*}=(1-d)^{(1-d)}(1-d g)^{(d-1)} e g^{(1-d)}\left(S_{h}+S_{f}\right)^{d}\left(U_{h}+U_{f}\right)^{(1-d)} \\
& \text { (A10) } \mathrm{T}^{*}=(1-\mathrm{g}) \mathrm{t}(1-\mathrm{dg})^{-1}\left(\mathrm{U}_{\mathrm{h}}+\mathrm{U}_{\mathrm{f}}\right)
\end{aligned}
$$

\section{Endowment $B$}

For endowment points such as $B$ without multinationals, the following seven equations characterize the equilibrium, with the subscripts $h$ and $f$ designating home and foreign values, respectively. 15 Equation (A11) is the zero-profit condition for home computer production.

$$
\text { (A11) } \mathrm{Kw}_{\mathrm{sh}} \mathrm{d}_{\mathrm{w}_{\mathrm{uh}}}{ }^{(1-\mathrm{d})}=\mathrm{P}
$$

Equations (A12) and (A13) are zero-profit conditions for foreign textile and computer production, respectively.

$$
\text { (A12) } w_{u f} / t=1
$$

${ }^{15}$ Clearly, $B_{h}{ }^{*}=e S_{h}{ }^{d} U_{h}(1-d)$. 
(A13) $\mathrm{Kw}_{\text {sf }} \mathrm{d}_{\mathrm{uf}}(1-\mathrm{d})=\mathrm{P}$

Equation (A14) is the factor-markets clearing condition for home (because home makes only computers, the two equations for the two markets can be simplified into this one equation).

$$
\text { (A14) } \mathrm{w}_{\mathrm{uh}} / \mathrm{w}_{\mathrm{sh}}=(1-\mathrm{d}) \mathrm{S}_{\mathrm{h}} / \mathrm{dU}_{\mathrm{h}}
$$

Equations (A15) and (A16) are the two factor-market clearing conditions for foreign.

$$
\begin{aligned}
& \text { (A15) } d \mathrm{Kw}_{\mathrm{sf}}{ }^{(\mathrm{d}-1)} \mathrm{w}_{\mathrm{uf}}{ }^{(1-\mathrm{d})} \mathrm{C}_{\mathrm{f}}=\mathrm{S}_{\mathrm{f}} \\
& \text { (A16) (1-d)Kw } \mathrm{sf}^{\mathrm{d}} \mathrm{w}_{\mathrm{uf}}{ }^{-\mathrm{d}} \mathrm{C}_{\mathrm{f}}+\mathrm{T}_{\mathrm{f}} / \mathrm{t}=\mathrm{U}_{\mathrm{f}}
\end{aligned}
$$

Finally, equation (A17) is the goods-market clearing condition which sets the value of world textile production equal to the fraction $(1-\mathrm{g})$ of world income.

$$
\text { (A17) } \mathrm{T}_{\mathrm{f}}=(1-\mathrm{g})\left(\mathrm{w}_{\mathrm{uh}} \mathrm{U}_{\mathrm{h}}+\mathrm{w}_{\mathrm{sh}} \mathrm{S}_{\mathrm{h}}+\mathrm{w}_{\mathrm{uf}} \mathrm{U}_{\mathrm{f}}+\mathrm{w}_{\mathrm{sf}} \mathrm{S}_{\mathrm{f}}\right)
$$

These seven equations determine the values for the seven endogenous variables $\mathrm{w}_{\mathrm{sh}}, \mathrm{w}_{\mathrm{uh}}$, $\mathrm{w}_{\mathrm{sf}}, \mathrm{w}_{\mathrm{uh}}, \mathrm{P}, \mathrm{C}_{\mathrm{f}}$, and $\mathrm{T}_{\mathrm{f}}$. Unfortunately, the non-linearity of the equations do not allow a closedform analytic solution for these variables. However, any given set of parameters does generate a unique solution. To see this solve the above system of equations for $\mathrm{w}_{\mathrm{sf}}$ to obtain the following equation which determines the equilibrium value $\mathrm{w}_{\mathrm{sf}}{ }^{*}$ :

$$
\text { (A18) }\left\{(1-d g) S_{f} / d f\right\} w_{s f}{ }^{*}+\left\{(1-g)(1-d)(d-1) d^{-d} d_{t}^{-d} S_{h}{ }^{d} U_{h}(1-d)\right\} w_{s f}{ }^{* d}=g U_{f} \text {. }
$$

The non-linearity of this equation in $\mathrm{w}_{\mathrm{sf}}{ }^{*}$ prevents solving it explicitly for $\mathrm{w}_{\mathrm{sf}}{ }^{*}$. It can be easily shown, however, that a unique solution for $\mathrm{w}_{\mathrm{sf}}{ }^{*}$ exists. Given the assumptions about the parameters, both terms in the brackets are positive; in addition, $d$ lies in the unit interval. It therefore follows that the left-hand side is monotonically increasing in $\mathrm{w}_{\mathrm{sf}}{ }^{*}$. Thus, for any value of $\mathrm{gU}_{\mathrm{f}}>0$, a unique value of $\mathrm{w}_{\mathrm{sf}}{ }^{*}$ satisfies equation (A18). Given this $\mathrm{w}_{\mathrm{sf}}{ }^{*}$, the equilibrium values of the six other endogenous variables can be found. This is the approach used for the numerical example in the text.

\section{Appendix B: Description of the BEA Censuses and Surveys}

\section{General Methodology}

Multinational corporations are obliged under the International Investment and Trade in Services Survey Act to participate in BEA censuses and surveys. Data for both the parent and affiliates are requested from someone located in the parent, but someone located in the affiliate may report the affiliate information.

The BEA defines parents and affiliates as described earlier. Determining whether the parent has at least a $10 \%$ ownership stake in the affiliate can be complicated when there is more than one ownership link between the parent and affiliate. In these cases, the percentages of ownership for each link are determined and then multiplied to determine the parent's overall stake in the affiliate. Affiliates must be business enterprises--i.e., must be an organization established to make a profit 
or otherwise secure economic advantage. Parents, however, need not be business enterprises: they may also be an individual, a non-profit organization such as a charity, a government, etc. In identifying U.S. parents, residence in rather than citizenship of the U.S. is the relevant criterion.

The censuses (also called "benchmark surveys") sample every American multinational and collect data on both the U.S. parent and its foreign affiliate(s) as defined earlier. The BEA identifies these multinationals both by checking whether each multinational from the previous census has "died" and by monitoring news services for the "birth" of new multinationals since that census. Substantive data must be reported by only those multinationals with at least one affiliate whose total assets, sales, or net income/loss exceeds $\$ 3$ million. Multinationals not meeting this criterion need to report only their name, employer identification number, and the number of affiliates. In practice, these "small" multinationals account for negligible amounts of activity: in 1989 they accounted for only $0.3 \%$ of total affiliate assets and $0.4 \%$ of total affiliate net income. The data reported in censuses as covering "all foreign affiliates" actually refers to only those affiliates meeting this size criterion. It is possible that some bias is introduced by ignoring these "small" multinationals. For example, if these firms operate extremely labor-intensive affiliates then the reported data may under-document the extent of outsourcing.

The surveys in non-benchmark years sample every American multinational which reported in the most recent benchmark survey at least one affiliate whose total assets, sales, or net income/loss exceeds $\$ 15$ million. The BEA identifies these multinationals using the same procedure as described above for the census years. Data collected in these non-benchmark years is less comprehensive than the data collected in the census years. From these data, the BEA calculates growth rates in activity for these parents and affiliates in various industry and country groupings. It then assumes the same growth rates for parents and affiliates of multinationals with affiliates in the $\$ 3$ million to $\$ 15$ million range in the same groupings. Thus, the BEA obtains estimates for all multinationals in the survey years.

Data are required to be reported on a fiscal-year basis. For example, the 1989 fiscal year is defined as the multinational's financial-reporting year that ended in calendar year 1989. Companies can have fiscal years which do not exactly coincide with calendar years. Multinational births and existing multinationals which acquire new affiliates during the fiscal year are required to report data as if the new operations had existed the entire year. For example, annual compensation at a newly acquired affiliate should cover the entire fiscal year's compensation at that enterprise-some of which was paid by the previous owner--and not just the compensation paid by the parent since acquisition.

Data are required to be reported following generally accepted accounting principles in the U.S. In particular, this means monetary amounts must be reported in U.S. dollars. Affiliate activity involving foreign currencies must be translated into dollars according to Financial Accounting 
Standards Board Statement \#52. Under these rules, assets and liabilities are to be converted to dollars using spot exchange rates quoted on the date of the balance sheet. Revenues and expenses are to be converted to dollars using average spot exchange rates during the relevant reporting year. Classification of Parents and Affiliates by Country and Industry

Each affiliate is classified by its country of location--i.e., the country in which its physical assets are located and in which its primary activity is conducted. This country need not be the country in which the affiliate is incorporated.

Each parent or affiliate is classified by 3-digit SIC industry according to a three-step procedure. First, the parent or affiliate is classified in the one-digit industry that accounts for the largest percentage of its sales. Second, within that one-digit industry it is classified in the two-digit industry that accounts for the largest percentage of its sales. Third, within that two-digit industry it is classified in the three-digit industry that accounts for the largest percentage of its sales. Note that this classification is at the enterprise level, not the establishment or activity level. For the 1989 census the BEA also separately classified parents and affiliates by activities. Comparing the two classifications indicates only very small differences for affiliates and slightly larger ones for parents: this is consistent with affiliates being much less diversified than parents.

\section{Definitions of Various Measures}

Companies must report all dollar amounts rounded to the nearest thousand dollars. However, they must report unrounded employment figures.

Sales $\equiv$ gross sales minus returns, allowances, and discounts, or gross operating revenues net value-added taxes and excise taxes

Employment $\equiv$ number of full and part-time employees on the payroll either at fiscal-year end or at some representative time during the year if fiscal-year end was unusual

Production employment $\equiv$ employees most directly connected with carrying out manufacturing activities of the business being reported, up to and including working foremen, but excluding other supervisory employees; they are those involved in the production of goods, related services (e.g., maintenance and repair), and auxiliary production for the plant's own use (e.g., power plant)

Compensation $\equiv$ wages, salaries, payments-in-kind, and employer expenditures for employee benefit plans

Net Property, Plant and Equipment $\equiv$ property, plant, and equipment involved in the production process less charges for depreciation, depletion, etc., measured at book value

Total Assets $\equiv$ current assets (accounts receivable, inventories, etc.) plus non-current assets (gross property, plant, and equipment, etc.) 


\section{References}

Anderson, R. and J. Thursby, "Confidence Intervals for Elasticity Estimators in Translog Models," Review of Economics and Statistics," 68, 1986, 647-657.

Baldwin, Robert E., "The Effect of Trade and Foreign Direct Investment on Employment and Relative Wages," NBER Working Paper \#5037, February 1995.

Berman, Eli, John Bound, and Zvi Griliches, "Changes in the Demand for Skilled Labor Within U.S. Manufacturing Industries: Evidence from the Annual Survey of Manufactures," Quarterly Journal of Economics, May 1994, 367-398.

Berman, Eli, John Bound, and Zvi Griliches, "Changes in the Demand for Skilled Labor Within U.S. Manufacturing Industries: Evidence from the Annual Survey of Manufactures," NBER Working Paper \#4255, 1993.

Berndt, Ernst, The Practice of Econometrics: Classic and Contemporary, Reading, MA: Addison-Wesley Publishing, 1991.

Bhagwati, Jagdish, "Trade and Wages: Alternative Theoretical Approaches," mimeograph presented at Brookings Conference on Trade and Wages, February 1995.

Bluestone, Barry and Bennett Harrison, The Deindustrialization of America: Plant Closings, Community Abandonment, and the Dismantling of Industry, New York: Basic Books 1982.

Borjas, George J., Richard B. Freeman, and Lawrence F. Katz, "On the Labor Market Effects of Immigration and Trade," NBER Working Paper \#3761, June 1991.

Borjas, George J. and Valerie A. Ramey, "Foreign Competition, Market Power, and Wage Inequality: Theory and Evidence," NBER Working Paper \#4556, December 1993.

Bound, John and George Johnson, "Changes in the Structure of Wages in the 1980s: An Evaluation of Alternative Explanations," American Economic Review, June 1992, 371-92.

Davis, Steven J., "Comment on Lawrence and Slaughter," Brookings Papers on Economic Activity: Microeconomics 2, 1993, 214-221.

Davis, Steven J., "Cross-Country Patterns of Change in Relative Wages," in Olivier J. Blanchard and Stanley Fischer (eds), 1992 Macroeconomics Annual, NBER, 1992.

Feenstra, Robert C. and Gordon Hanson, "Foreign Investment, Outsourcing, and Relative Wages," NBER Working Paper \#5121, May 1995.

Freeman, Richard B., "How Much Has Deunionization Contributed to the Rise in Male Earnings Inequality?" in Sheldon Danziger and Peter Gottschalk (eds), Uneven Tides: Rising Inequality in America, New York: Russel Sage Foundation, 1993, 133-163.

Hamermesh, Daniel S., Labor Demand, Princeton: Princeton University Press, 1993.

Helpman, Elhanan, "A Simple Theory of International Trade with Multinational Corporations," Journal of Political Economy, 92, 1984, No. 3, 451-471. 
Helpman, E. and P. Krugman, Market Structure and Foreign Trade, Cambridge: MIT, 1985.

"The Hollow Corporation," Business Week, March 3, 1986.

Katz, Lawrence F. and Kevin M. Murphy "Changes in Relative Wages, 1963-1987: Supply and Demand Factors" Quarterly Journal of Economics, June 1992, 35-77.

Kravis, Irving B. and Robert E. Lipsey, "The Effect of Multinational Firms' Operations on their Domestic Employment," NBER Working Paper \#2760, November 1988.

Krueger, Alan B. "How Computers Have Changed the Wage Structure: Evidence from Microdata, 1984-89," Quarterly Journal of Economics, 108, February 1993, 33-60.

Krugman, Paul, "Growing World Trade: Causes and Consequences," Brookings Papers on Economic Activity 1, 1995, 327-377.

Lawrence, Robert Z. and Matthew J. Slaughter, "International Trade and American Wages in the 1980's: Giant Sucking Sound or Small Hiccup?" Brookings Papers on Economic Activity: Microeconomics 2, 1993, 161-211.

Lipsey, Robert E., "Outward Direct Investment and the U.S. Economy," NBER Working Paper \#4691, March 1994.

Lipsey, Robert E., Irving B. Kravis, and Romualdo A. Roldan, "Do Multinational Firms Adapt Factor Proportions to Relative Factor Prices," in Anne Krueger (ed.) Trade and Employment in Developing Countries, Chicago: University of Chicago Press, 1982, 215-255.

Markusen, James, "The Boundaries of Multinational Enterprises and the Theory of International Trade," Journal of Economic Perspectives, Spring 1995, 169-189.

Mishel, Lawrence and Jared Bernstein, "Is the Technology Black Box Empty?: An Empirical Examination of the Impact of Technology on Wage Inequality," mimeo, April 1994.

Moody's Investor Service, various corporate bond rates, from Federal Reserve Bulletin.

Oman, Charles, New Forms of Investment in Developing Countries, Paris: OECD Development Center, 1989.

Sachs, Jeffrey D. and Howard J. Shatz, "Trade and Jobs in U.S. Manufacturing," Brookings Papers on Economic Activity: 1994, 1, 1-69.

Slaughter, Matthew J., "International Trade, Multinational Corporations, and American Wage Divergence in the 1980's," MIT Industrial Performance Center Working Paper 93-010WP, November, 1993.

United States Department of Commerce, Bureau of Economic Analysis, United States Direct Investment Abroad, various years, 1977 through 1989.

United States Internal Revenue Service, Statistics of Income Bulletin, various years.

Wheeler, David and Ashoka Mody, "International Investment Location Decisions," Journal of International Economics, 33, 1992, pp 57-76. 
Figure 1: Possible Equilibria Without Multinationals

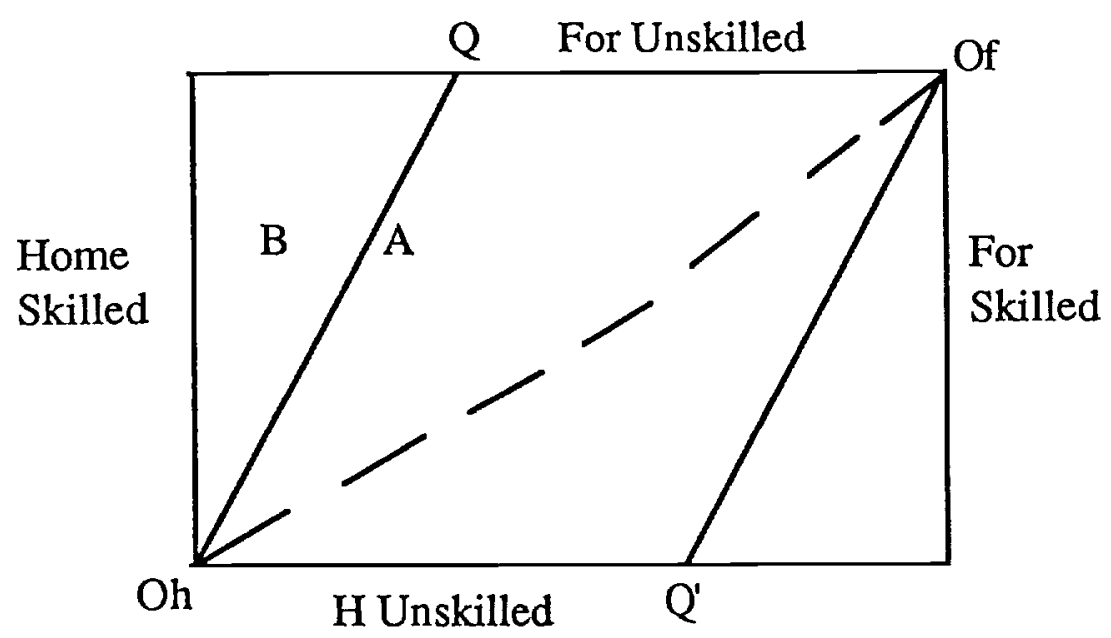

$\mathrm{A}$ and $\mathrm{B}$ are two representative endowment points between home and foreign. $\mathrm{O}_{\mathrm{hQ}}$ and $\mathrm{O}_{\mathrm{fQ}}$ are the production rays for computers in the integrated equilibrium. $\mathrm{QO}_{\mathrm{f}}$ and $\mathrm{Q}^{\prime} \mathrm{O}_{\mathrm{h}}$ are the production rays for textiles in the integrated equilibrium.

Figure 2: Possible Equilibria With Multinationals

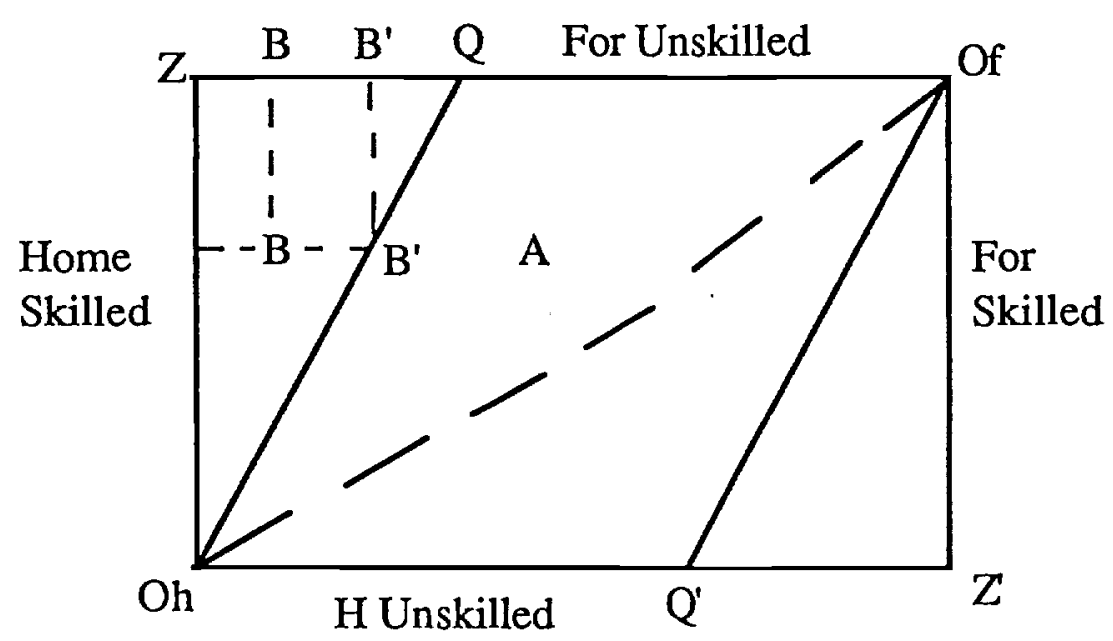

$A$ and $B$ are two representative endowment points between home and foreign.

$B^{\prime}$ is the production point that multinationals settle at when the endowment point is $B$.

$\mathrm{O}_{\mathrm{h}} \mathrm{Z}$ and $\mathrm{O}_{\mathrm{f}} \mathrm{Z}^{\prime}$ are the production rays for headquarter services in the multinational equilibrium.

$Z Q$ and $Z^{\prime} Q^{\prime}$ are the production rays for assembly in the multinational equilibrium.

$\mathrm{QO}_{\mathrm{f}}$ and $\mathrm{Q}^{\prime} \mathrm{O}_{\mathrm{h}}$ are the production rays for textiles in the multinational equilibrium. 
Table 1: Equilibrium Values of Model With and Without Multinationals

\begin{tabular}{ccc}
\hline \hline Endogenous Variable & Without Multinationals & With Multinationals \\
\hline $\mathrm{w}_{\mathrm{sh}}{ }^{*}$ & 1.69 & 1.29 \\
$\mathrm{w}_{\mathrm{uh}}{ }^{*}$ & 5.06 & 1.00 \\
$\left(\mathrm{w}_{\mathrm{sh}}{ }^{*} / \mathrm{w}_{\mathrm{uh}}{ }^{*}\right)$ & 0.33 & 1.29 \\
$\mathrm{w}_{\mathrm{sf}}{ }^{*}$ & 2.89 & 1.29 \\
$\mathrm{w}_{\mathrm{uf}}$ & 1.00 & 1.00 \\
$\left.{ }^{*} \mathrm{w}_{\mathrm{sf}}{ }^{*} / \mathrm{w}_{\mathrm{uf}}{ }^{*}\right)$ & 2.89 & 1.29 \\
$\mathrm{P}^{*}$ & 3.89 & 2.12 \\
$\mathrm{U}_{\mathrm{fh}}{ }^{*}$ & 0.00 & 2.86 \\
Exports of HQ & 0.00 & 6.67 \\
\hline
\end{tabular}

Notes: These values come from a numeric simulation of the outsourcing model. The model solves for an endowment such as point B in Figure 2 both without and with multinationals. See text for the parameter values used. $U_{\mathrm{fh}}{ }^{*}$ is unskilled labor employed by home-headquartered multinationals in foreign affiliates.

Table 2: The 32 BEA Manufacturing Industries

\begin{tabular}{cccc}
\hline \hline Name & SIC Codes & Name & SIC Codes \\
\hline Bakery products & 204,205 & Radio and TV appliances & 365,366 \\
Beverages & 208 & Electronics, ex. computers & 367 \\
Other bakery products & $206,207,209$ & Other electronic machinery & $361,362,364,369$ \\
Industrial chemicals & $281,282,286$ & Motor vehicles & 371 \\
Drugs & 283 & Other transportation & $372-376,379$ \\
Soaps and cleaners & 284 & Tobacco & 21 \\
Agricultural chemicals & 287 & Textiles and apparel & 22,23 \\
Other chemical products & 285,289 & Lumber and furniture & 24,25 \\
Primary metals, ferrous & $331,332,339$ & Paper and allied products & $261-263,265,267$ \\
Primary metals, nonferrous & $331-336$ & Printing and publishing & 27 \\
Fabricated metal products & 34 & Rubber products & $301,302,305,306$ \\
Farm and garden machinery & 352 & Plastic products & 308 \\
Construction machinery & 353 & Glass products & $321-323$ \\
Computers & 357 & Clay and stone products & $324-329$ \\
Other machinery & 359 & Instruments & 38 \\
Household appliances & 363 & Other manufactures & 39 \\
\hline
\end{tabular}

Sources: BEA Guide to Industry and Foreign Trade Classifications for International Surveys 
Table 3: Number of Parents and Affiliates

\begin{tabular}{ccc}
\hline \hline Year & Number of Parents & Number of Affiliates \\
\hline 1977 & 1,842 & 9,712 \\
1982 & 1,215 & 7,005 \\
1983 & 1,240 & 6,887 \\
1984 & 1,223 & 6,877 \\
1985 & 1,196 & 6,793 \\
1986 & 1,184 & 6,787 \\
1987 & 1,182 & 6,688 \\
1988 & 1,154 & 6,741 \\
1989 & 1,312 & 7,552 \\
\hline
\end{tabular}

Notes: These are for U.S. manufacturing multinationals--parents located in the U.S. and affiliates located abroad. The affiliates include both majority-owned and minority-owned affiliates.

Sources: The Bureau of Economic Analysis

Table 4: Total Employment

\begin{tabular}{|c|c|c|c|c|c|}
\hline Year & $\begin{array}{c}\text { Affiliates, } \\
\text { Majority-Owned }\end{array}$ & $\begin{array}{l}\text { Affiliates, } \\
\text { All }\end{array}$ & $\begin{array}{c}\text { Parents of } \\
\text { Maj.-Own Affs }\end{array}$ & $\begin{array}{c}\text { Parents of } \\
\text { All Affiliates }\end{array}$ & $\begin{array}{c}\text { U.S. } \\
\text { Manufacturing }\end{array}$ \\
\hline 1977 & 3,773 & 4,849 & 11,009 & 11,775 & 18,509 \\
\hline 1982 & 3,358 & 4,429 & 10,268 & 10,533 & 17,828 \\
\hline 1983 & 3,201 & 4,230 & $-\cdots$ & 10,403 & 17,465 \\
\hline 1984 & 3,245 & 4,370 & $\cdots$ & 10,660 & 17,871 \\
\hline 1985 & 3,202 & 4,349 & ---- & 10,503 & 17,503 \\
\hline 1986 & 3,092 & 4,121 & $-\cdots$ & 10,431 & 17,086 \\
\hline 1987 & 3,031 & 4,118 & -.-.- & 10,196 & 17,715 \\
\hline 1988 & 3,058 & 4,144 & $-\cdots$ & 9,820 & 17,968 \\
\hline 1989 & 3,247 & 4,191 & 9,943 & 10,127 & 17,794 \\
\hline$\% \Delta, ' 77-' 82$ & -11.0 & -8.7 & -6.7 & -10.5 & -3.7 \\
\hline$\% \Delta, ' 82-' 89$ & -3.3 & -5.4 & -3.2 & -3.9 & -0.2 \\
\hline$\% \Delta, ' 77-' 89$ & -14.0 & -13.6 & -9.7 & -14.0 & -3.9 \\
\hline
\end{tabular}

Notes: All employment figures are in thousands of workers and are for manufacturing. Parents are located in the U.S., and affiliates are located abroad. U.S. manufacturing data covers only establishments where production actually occurs: they do not cover non-production workers employed at auxiliary locations.

Sources: Data for affiliates and parents come from the Bureau of Economic Analysis. Data for U.S. manufacturing comes from the NBER's Trade and Immigration Data Base and Wayne Gray. 
Table 5: Non-Production and Production Employment

\begin{tabular}{ccccccc}
\hline \hline & \multicolumn{3}{c}{ Production } & \multicolumn{3}{c}{ Non-Production } \\
\hline Year & Affiliates & Parents & U.S. mfg. & Affiliates & Parents & U.S. mfg \\
\hline 1977 & 2,371 & 6,733 & 13,686 & 1,402 & 4,276 & 4,823 \\
1982 & 1,941 & 4,763 & 12,403 & 1,417 & 5,505 & 5,425 \\
1989 & 1,875 & 4,541 & 12,356 & 1,372 & 5,402 & 5,438 \\
$\% \Delta, ' 77-' 82$ & -18.1 & -29.3 & -9.4 & $+1: 1$ & +28.7 & +12.5 \\
$\% \Delta, ' 82-' 89$ & -3.4 & -4.7 & -0.4 & -3.2 & -1.9 & +0.2 \\
$\% \Delta, ' 77-' 89$ & -20.9 & -32.6 & -9.7 & -2.1 & +26.3 & +12.8 \\
\hline
\end{tabular}

Notes: All employment figures are in thousands of workers. Affiliates are majority-owned manufacturing affiliates. Parents are of majority-owned manufacturing affiliates. U.S. manufacturing data covers only establishments where production actually occurs: they do not cover non-production workers employed at auxiliary locations.

Sources: Data for affiliates and parents come from the Bureau of Economic Analysis. Data for U.S. manufacturing comes from the NBER's Trade and Immigration Data Base and Wayne Gray.

Table 6: Production Hours

\begin{tabular}{cccc}
\hline \hline Year & Affiliates & Parents & U.S. mfg \\
\hline 1977 & 4,403 & 12,960 & 26,682 \\
1982 & 3,622 & 9,137 & 23,548 \\
1989 & 3,508 & $-\ldots--$ & 24,662 \\
$\% \Delta, ' 77-' 82$ & -17.7 & -29.5 & -11.7 \\
$\% \Delta, ' 82-' 89$ & -3.1 & $-\cdots-$ & +4.7 \\
$\% \Delta, ' 77-' 89$ & -20.3 & $-\cdots-$ & -7.6 \\
\hline
\end{tabular}

Notes: All hours figures are in millions of hours. Affiliates are majority-owned manufacturing affiliates. Parents are of majority-owned manufacturing affiliates.

Sources: Data for affiliates and parents come from the Bureau of Economic Analysis. Data for U.S. manufacturing comes from the NBER's Trade and Immigration Data Base and Wayne Gray. 
Table 7: Affiliate Employment by Country

\begin{tabular}{ccccccc}
\hline \hline Country & $\begin{array}{c}\text { Prod Empl } \\
1977\end{array}$ & $\begin{array}{c}\text { Prod Empl } \\
1989\end{array}$ & $\begin{array}{c}\text { Prod Empl } \\
\text { Level } \Delta\end{array}$ & $\begin{array}{c}\text { Relative Wage } \\
1977\end{array}$ & $\begin{array}{c}\text { Relative Wage } \\
1989\end{array}$ & $\begin{array}{c}\text { Relative Wage } \\
\text { Level } \Delta\end{array}$ \\
\hline World & 2,371 & 1,875 & -495 & 0.56 & 0.56 & 0.00 \\
Europe & 1,202 & 831 & -371 & 0.67 & 0.79 & +0.11 \\
Canada & 358 & 271 & -77 & 0.95 & 0.91 & -0.04 \\
Mexico & 103 & 184 & +81 & 0.24 & 0.12 & -0.11 \\
Other Am & 344 & 269 & -75 & 0.25 & 0.18 & -0.07 \\
SE Asia & 203 & 197 & -6 &.--- & ---- &.-- \\
HongKong & 24 & 23 & -1 & 0.14 & 0.16 & +0.02 \\
India & 19 & 4 & -16 & 0.10 & 0.08 & -0.02 \\
Indonesia & 8 & 4 & -4 & 0.09 & 0.10 & +0.01 \\
Malaysia & 19 & 35 & +16 & 0.08 & 0.10 & +0.02 \\
Philippines & 45 & 37 & -8 & 0.07 & 0.08 & +0.02 \\
Singapore & 27 & 37 & +10 & 0.11 & 0.17 & +0.06 \\
S Korea & 10 & 14 & +4 & 0.16 & 0.24 & +0.08 \\
Taiwan & 45 & 27 & -18 & 0.08 & 0.25 & +0.17 \\
Thailand & 5 & 17 & +12 & 0.07 & 0.06 & -0.01 \\
\hline
\end{tabular}

Notes: These data are for majority-owned manufacturing affiliates. "Prod Empl" is production employment in thousands of workers. "Relative Wage" is the average hourly compensation rate paid by majority-owned manufacturing affiliates for production workers in that country divided by the average hourly compensation rate paid by all U.S. parents of all majority-owned affiliates. "Other Am" consists of all Central-and South-American countries other than Mexico. "SE Asia" consists of all South-East Asian countries listed below its line in the table.

Sources: The Bureau of Economic Analysis. 
Table 8: Affiliatc Employment by Industry

\begin{tabular}{|c|c|c|c|c|c|c|c|c|c|c|c|c|}
\hline SC & industry & Prod Emp & Prod Emp & Level Change & $\%$ Change & NonProd Emp & NonProd Emp & Level Change & $\%$ Change & Prod Share & Prod Share & Level Change \\
\hline Code & Name & 1977 & 1989 & & & 1977 & 1989 & & & 1977 & 1989 & \\
\hline 204 & GrainMill & 48,522 & 45,800 & $-2,722$ & -5.61 & 26,149 & 27,200 & 1,051 & 4.02 & 0.65 & 0.63 & -0.02 \\
\hline 208 & Beverages & 23,475 & 15,700 & $-7,775$ & -33.12 & 23,353 & 18,200 & $-5,153$ & -22.07 & 0.50 & 0.46 & -0.04 \\
\hline 209 & OtherBakery & 176,329 & 122,400 & $-53,929$ & -30.58 & 79,478 & 78,200 & $-1,278$ & -1.61 & 0.69 & 0.61 & -0.08 \\
\hline 210 & Tobacco & 22,491 & 26,500 & 4,009 & 17.82 & 14,141 & 14,000 & -141 & -1.00 & 0.61 & 0.65 & 0.04 \\
\hline 220 & TextApp & 80,303 & 58,500 & $-21,803$ & -27.15 & 21,228 & 23,200 & 1.972 & 9.29 & 0.79 & 0.72 & -0.07 \\
\hline 240 & WoodFurn & 29,901 & 27,200 & $-2,701$ & -9.03 & 9,717 & 9,800 & 83 & 0.85 & 0.75 & 0.74 & -0.02 \\
\hline 260 & Paper & 68,587 & 81,500 & 12,913 & 18.83 & 30,262 & 47,100 & 16,838 & 55.64 & 0.69 & 0.63 & -0.06 \\
\hline 270 & Printing & 13,943 & 16,500 & 2,557 & 18.34 & 13,282 & 15,900 & 2,618 & 19.71 & 0.51 & 0.51 & 0.00 \\
\hline 281 & Chemicals & 85,588 & 73,100 & $-12,488$ & -14.59 & 60,775 & 61,200 & 425 & 0.70 & 0.58 & 0.54 & -0.04 \\
\hline 283 & Drugs & 73,285 & 65,600 & $-7,685$ & -10.49 & 83,844 & 87,200 & 3,356 & 4.00 & 0.47 & 0.43 & -0.04 \\
\hline 284 & Soaps & 47,719 & 54,500 & 6,781 & 14.21 & 59,585 & 70,000 & 10,415 & 17.48 & 0.44 & 0.44 & -0.01 \\
\hline 287 & AgriChems & 8,108 & 4,800 & $-3,308$ & -40.80 & 6,519 & 4,600 & $.1,919$ & -29.44 & 0.55 & 0.51 & .0 .04 \\
\hline 289 & OtherChems & 18,514 & 29,400 & 10,886 & 58.80 & 20,500 & 24,300 & 3,800 & 18.54 & 0.47 & 0.55 & 0.07 \\
\hline 301 & Rubber & 82,280 & 52,200 & $-30,080$ & -36.56 & 62,882 & 40,000 & $-22,882$ & -36.39 & 0.57 & 0.57 & 0.00 \\
\hline 308 & Plastics & 20,059 & 28,600 & 8,541 & 42.58 & 7,883 & 15,700 & 7,817 & 99.16 & 0.72 & 0.65 & -0.07 \\
\hline 321 & Glass & 27,198 & 21,400 & $-5,798$ & -21.32 & 9,862 & 7,900 & $-1,962$ & -19.89 & 0.79 & 0.73 & -0.06 \\
\hline 324 & Stone & 40,991 & 23,600 & $-17,391$ & -42.43 & 17,543 & 12,200 & $-5,343$ & -30.46 & 0.77 & 0.66 & -0.11 \\
\hline 331 & FerrousMetal & 21,310 & 5,900 & $-15,410$ & -72.31 & 6,758 & 2,900 & $-3,858$ & -57.09 & 0.76 & 0.67 & -0.09 \\
\hline 333 & NonFerMetal & 21,680 & 17,800 & $-3,880$ & -17.90 & 10,952 & 7,100 & $-3,852$ & -35.17 & 0.66 & 0.71 & 0.05 \\
\hline 340 & FabricMetal & 114,998 & 93,000 & $-21,998$ & -19.13 & 53,276 & 52,200 & $-1,076$ & -2.02 & 0.68 & 0.64 & -0.04 \\
\hline 352 & FarmMach & 31,155 & 17,100 & $-14,055$ & -45.11 & 19,307 & 9,000 & $-10,307$ & -53.38 & 0.62 & 0.66 & 0.04 \\
\hline 353 & ConstrMach & 75,176 & 34,800 & $-40,376$ & -53.71 & 49,297 & 35,600 & $-13,697$ & -27.78 & 0.60 & 0.49 & -0.11 \\
\hline 357 & Computers & 65,354 & 102,800 & 37,446 & 57.30 & 124,589 & 142,000 & 17,411 & 13.97 & 0.34 & 0.42 & 0.08 \\
\hline 359 & OtherMach & 98,785 & 99,500 & 715 & 0.72 & 59,571 & 67,100 & 7,529 & 12.64 & 0.62 & 0.60 & -0.03 \\
\hline 363 & Appliances & 58,437 & 50,100 & $-8,337$ & -14.27 & 37,194 & 25,400 & $-11,794$ & -31.71 & 0.61 & 0.66 & 0.05 \\
\hline 365 & RadioTV & 147,466 & 22,700 & $-124,766$ & -84.61 & 80,104 & 15,100 & $-65,004$ & -81.15 & 0.65 & 0.60 & -0.05 \\
\hline 367 & ElectParts & 135,164 & 155,800 & 20,636 & 15.27 & 49,552 & 83,700 & 34,148 & 68.91 & 0.73 & 0.65 & -0.08 \\
\hline 369 & OtherElec & 80,533 & 58,900 & $-21,633$ & -26.86 & 40,329 & 43,000 & 2,671 & 6.62 & 0.67 & 0.58 & -0.09 \\
\hline 371 & Cars & 494,648 & 346,400 & $-148,248$ & -29.97 & 224,568 & 216,100 & $-8,468$ & -3.77 & 0.69 & 0.62 & -0.07 \\
\hline 372 & OtherTrans & 12,529 & 19,000 & 6,471 & 51.65 & 8,735 & 15,200 & 6,465 & 74.01 & 0.59 & 0.56 & -0.03 \\
\hline 380 & Instruments & 86,940 & 76,200 & $-10,740$ & -12.35 & 68,292 & 84,200 & $.15,908$ & 23.29 & 0.69 & 0.48 & .0 .22 \\
\hline 390 & Other & 59,223 & 28,100 & $-31,123$ & -52.55 & 23,117 & 16,100 & $-7,017$ & -30.35 & 0.78 & 0.64 & -0.15 \\
\hline & & & & & & & & & & & & \\
\hline & Totals & $2,370,691$ & $1,875,400$ & $-495,291$ & -20.89 & $1,402,644$ & $1,371,400$ & $-31,244$ & -2.23 & 0.63 & 0.58 & -0.05 \\
\hline & \multirow{2}{*}{\multicolumn{12}{|c|}{ All data are for majority-owned manufacturing affiliates. }} \\
\hline Notes: & & & & & & & & & & & & \\
\hline & \multirow{2}{*}{\multicolumn{12}{|c|}{$\begin{array}{l}\text { - Non)Prod Emp" is (non)production employment measured in thousands of workers. } \\
\text { "Prod Share" is the share of production employment in total affilate employment }\end{array}$}} \\
\hline & & & & & otal affilate e & mployment. & & & & & & \\
\hline Sources: & \multicolumn{3}{|c|}{ The Bureau of Economic Analysis } & & & & & & & & & \\
\hline
\end{tabular}


Table 9: Capital Stock by Industry

\begin{tabular}{|c|c|c|c|c|c|c|c|c|}
\hline SC & Industry & Affiliate PPE & Aftiliate PPE & Annualized & Parent PPE & Parent PPE & Annualized & Difference \\
\hline Code & Name & 1977 & 1989 & Growth Rate & 1977 & 1989 & Growth Rate & (Aff-Par) \\
\hline 204 & GrainMill & 902 & 3,230 & 0.11 & 2,823 & 9,584 & 0.11 & 0.00 \\
\hline 208 & Beverages & 754 & 1,503 & 0.06 & 2,160 & 15,331 & 0.18 & -0.12 \\
\hline 209 & OtherBakery & 2,012 & 4,978 & 0.08 & 9,338 & 31,914 & 0.11 & -0.03 \\
\hline 210 & Tobacco & 407 & 1,406 & 0.11 & 3,385 & 7,754 & 0.07 & 0.04 \\
\hline 220 & TextApp & 576 & 974 & 0.04 & 4,018 & 5,867 & 0.03 & 0.01 \\
\hline 240 & WoodFurn & 527 & 1,046 & 0.06 & 7,641 & 13,631 & 0.05 & 0.01 \\
\hline 260 & Paper & 2,452 & 8,729 & 0.11 & 10,567 & 34,062 & 0.10 & 0.01 \\
\hline 270 & Printing & 125 & 688 & 0.15 & 2,449 & 13,531 & 0.15 & 0.00 \\
\hline 281 & Chemicals & 5,715 & 14,546 & 0.08 & 24,497 & 48,417 & 0.06 & 0.02 \\
\hline 283 & Drugs & 1,543 & 4,594 & 0.10 & 4,647 & 20,064 & $0: 13$ & -0.03 \\
\hline 284 & Soaps & 1,235 & 3,075 & 0.08 & 3,015 & 11,357 & 0.12 & -0.04 \\
\hline 287 & AgriChems & 470 & 404 & -0.01 & 1,500 & 4,113 & 0.09 & -0.10 \\
\hline 289 & OtherChems & 752 & 3,042 & 0.12 & 2,000 & 7,642 & 0.12 & 0.01 \\
\hline 301 & Rubber & 1,837 & 2,228 & 0.02 & 4,094 & 6,183 & 0.03 & -0.02 \\
\hline 308 & Plastics & 333 & 1,835 & 0.15 & 831 & 3,416 & 0.13 & 0.03 \\
\hline 321 & Glass & 429 & 1,433 & 0.11 & 1,967 & 3,964 & 0.06 & 0.05 \\
\hline 324 & Stone & 818 & 1,495 & 0.05 & 3,803 & 6,933 & 0.05 & 0.00 \\
\hline 331 & FerrousMetal & 422 & 217 & -0.05 & 19,636 & 6,857 & -0.08 & 0.03 \\
\hline 333 & NonFerMetal & 952 & 2,322 & 0.08 & 8,148 & 14,418 & 0.05 & 0.03 \\
\hline 340 & FabricMetal & 2,034 & 4,200 & 0.06 & 5,811 & 10,398 & 0.05 & 0.01 \\
\hline 352 & FarmMach & 286 & 646 & 0.07 & 1,323 & 2,000 & 0.04 & 0.04 \\
\hline 353 & ConstrMach & 1,000 & 1,828 & 0.05 & 4,485 & 5,460 & 0.02 & 0.04 \\
\hline 357 & Computers & 4,684 & 11,379 & 0.08 & 8,299 & 27,318 & 0.10 & -0.03 \\
\hline 359 & OtherMach & 1,083 & 3,083 & 0.09 & 5,809 & 12,800 & 0.07 & 0.02 \\
\hline 363 & Appliances & 396 & 1,520 & 0.12 & 909 & 2,256 & 0.08 & 0.04 \\
\hline 365 & RadioTV & 982 & 910 & -0.01 & 3,194 & 22,954 & 0.18 & -0.18 \\
\hline 367 & ElectParts & 600 & 4,443 & 0.18 & 1,147 & 6,753 & 0.16 & 0.02 \\
\hline 369 & OtherElec & 824 & 1,658 & 0.06 & 5,188 & 6,819 & 0.02 & 0.04 \\
\hline 371 & Cars & 6,366 & 20,790 & 0.10 & 16,175 & 50,185 & 0.10 & 0.00 \\
\hline 372 & OtherTrans & 99 & 733 & 0.18 & 10,198 & 24,878 & 0.08 & 0.10 \\
\hline 380 & Instruments & 1,125 & 4,462 & 0.12 & 4,638 & 20,669 & 0.13 & -0.01 \\
\hline 390 & Other & 411 & 584 & 0.03 & 1,729 & 6,000 & 0.11 & -0.08 \\
\hline Notes: & \multicolumn{5}{|c|}{ PPE is net property, plant, and equipment in book-value millions of dollars. } & & & \\
\hline & \multicolumn{4}{|c|}{ Affiliates are majority-owned manufacturing affiliates. } & & & & \\
\hline & \multicolumn{4}{|c|}{ Parents are of majority-owned manufacturing affiliates. } & & & & \\
\hline Sources: & \multicolumn{3}{|c|}{ The Bureau of Economic Analysis } & & & & & \\
\hline
\end{tabular}


Table 10: Sales by Industry

\begin{tabular}{|c|c|c|c|c|c|c|c|c|}
\hline$S x$ & Industry & Affiliate Sales & Affiliate Sales & Annualized & Parent Sales & Parent Sales & Annualized & Difference \\
\hline Code & Name & 1977 & 1989 & Growth Rate & 1977 & 1989 & Growth Rate & (Aff-Par) \\
\hline 204 & GrainMill & 5,702 & 14,858 & 0.08 & 14,497 & 33,306 & 0.07 & 0.01 \\
\hline 208 & Beverages & 3,018 & 9,598 & 0.10 & 9,679 & 36,253 & 0.12 & -0.02 \\
\hline 209 & OtherBakery & 13,036 & 26,336 & 0.06 & 59,245 & 121,059 & 0.06 & 0.00 \\
\hline 210 & Tobacco & 1,845 & 10,387 & 0.15 & 10,845 & 27,527 & 0.08 & 0.07 \\
\hline 220 & TextApp & 3,100 & 5,132 & 0.04 & 25,342 & 26,331 & 0.00 & 0.04 \\
\hline 240 & WoodFurn & 1,729 & 2,625 & 0.04 & 18,218 & 33,741 & 0.05 & -0.02 \\
\hline 260 & Paper & 5,091 & 17,594 & 0.11 & 22,570 & 68,213 & 0.10 & 0.01 \\
\hline 270 & Printing & 1,268 & 3,835 & 0.10 & 13,734 & 50,762 & 0.12 & -0.02 \\
\hline 281 & Chemicals & 13,716 & 40,908 & 0.10 & 53,985 & 108,869 & 0.06 & 0.04 \\
\hline 283 & Drugs & 7,277 & 22,793 & 0.10 & 16,423 & 58,257 & 0.11 & -0.01 \\
\hline 284 & Soaps & 6,964 & 18,637 & 0.09 & 14,790 & 42,678 & 0.09 & -0.01 \\
\hline 287 & AgriChems & 1,300 & 1,895 & 0.03 & 3,303 & 5,864 & 0.05 & -0.02 \\
\hline 289 & OtherChems & 3,138 & 10,418 & 0.11 & 7,974 & 20,063 & 0.08 & 0.03 \\
\hline 301 & Rubber & 5,764 & 9,092 & 0.04 & 16,401 & 15,533 & 0.00 & 0.04 \\
\hline 308 & Plastics & 1,195 & 6,525 & 0.15 & 3,251 & 12,563 & 0.12 & 0.03 \\
\hline 321 & Glass & 1,344 & 3,250 & 0.08 & 6,053 & 9,513 & 0.04 & 0.04 \\
\hline 324 & Stone & 2,414 & 4,384 & 0.05 & 10,409 & 13,385 & 0.02 & 0.03 \\
\hline 331 & FerrousMetal & 1,489 & 1,217 & -0.02 & 46,902 & 22,039 & -0.06 & 0.04 \\
\hline 333 & NonFerMetal & 2,298 & 4,491 & 0.06 & 19,250 & 36,881 & 0.06 & 0.00 \\
\hline 340 & FabricMetal & 7,773 & 15,324 & 0.06 & 28,411 & 45,807 & 0.04 & 0.02 \\
\hline 352 & FarmMach & 2,971 & 5,014 & 0.04 & 6,559 & 17,306 & 0.08 & -0.04 \\
\hline 353 & ConstrMach & 5,788 & 9,374 & 0.04 & 18,211 & 24,038 & 0.02 & 0.02 \\
\hline 357 & Computers & 13,389 & 67,982 & 0.14 & 23,950 & 87,484 & 0.11 & 0.03 \\
\hline 359 & OtherMach & 6,258 & 17,950 & 0.09 & 31,445 & 42,411 & 0.03 & 0.07 \\
\hline 363 & Appliances & 3,320 & 7,033 & 0.06 & 8,436 & 12,063 & 0.03 & 0.03 \\
\hline 365 & RadioTV & 6,911 & 6,007 & -0.01 & 16,723 & 81,179 & 0.14 & -0.15 \\
\hline 367 & ElectParts & 4,418 & 19,093 & 0.13 & 6,247 & 22,457 & 0.11 & 0.02 \\
\hline 369 & OtherElec & 4,006 & 7,544 & 0.05 & 31,225 & 30,578 & 0.00 & 0.06 \\
\hline 371 & Cars & 47,898 & 110,897 & 0.07 & 115,877 & 238,419 & 0.06 & 0.01 \\
\hline 372 & OtherTrans & 788 & 3,494 & 0.13 & 49,804 & 123,560 & 0.08 & 0.05 \\
\hline 380 & Instruments & 6,349 & 21,924 & 0.11 & 19,087 & 75,230 & 0.12 & -0.01 \\
\hline 390 & Other & 2,644 & 3,696 & 0.03 & 10,607 & 10,006 & 0.00 & 0.03 \\
\hline & Total & 194,201 & 509,307 & 0.08 & 739,453 & $1,553,375$ & 0.06 & 0.02 \\
\hline Notes: & \multicolumn{3}{|c|}{ Sales are in millions of dollars. } & & & & & \\
\hline & \multicolumn{4}{|c|}{ Affillates are majority-owned manufacturing affiliates. } & & & & \\
\hline & \multicolumn{4}{|c|}{ Parents are of majority-owned manufacturing affiliates. } & & & & \\
\hline Sources: & \multicolumn{3}{|c|}{ The Bureau of Economic Analysis } & & & & & \\
\hline
\end{tabular}


Table 11: Activity for Non-Manufacturing Multinationals

\begin{tabular}{ccccc}
\hline \hline Year & $\begin{array}{c}\text { Number of } \\
\text { Parents }\end{array}$ & $\begin{array}{c}\text { Number of } \\
\text { Affiliates }\end{array}$ & $\begin{array}{c}\text { Parent } \\
\text { Employment }\end{array}$ & $\begin{array}{c}\text { Affiliate } \\
\text { Employment }\end{array}$ \\
\hline 1977 & 1,698 & 14,954 & 7,640 & 2,493 \\
1982 & 1,030 & 11,334 & 8,887 & 2,387 \\
1989 & 960 & 11,347 & 9,490 & 2,563 \\
\hline
\end{tabular}

Notes: These data are for all non-manufacturing parents and affiliates--parents located in the U.S. and affiliates located abroad. The affiliates include both majority-owned and minority-owned affiliates.

Sources: The Bureau of Economic Analysis.

Table 12: IRS and BEA Data Comparison

\begin{tabular}{ccccccc}
\hline \hline Year & $\begin{array}{c}\text { \# of IRS } \\
\text { Parents }\end{array}$ & $\begin{array}{c}\text { \# of BEA } \\
\text { Parents }\end{array}$ & $\begin{array}{c}\text { \# of IRS } \\
\text { Affiliates }\end{array}$ & $\begin{array}{c}\text { \# of BEA } \\
\text { Affiliates }\end{array}$ & $\begin{array}{c}\text { IRS Aff } \\
\text { Sales }\end{array}$ & $\begin{array}{c}\text { BEA Aff } \\
\text { Sales }\end{array}$ \\
\hline $1977 / 1980$ & 1,849 & 1,842 & 10,038 & 9,712 & 338 & 298 \\
1982 & ---- & 1,215 & 7,862 & 7,005 & 324 & 359 \\
1984 & ---- & 1,223 & 7,259 & 6,887 & 341 & 376 \\
\hline
\end{tabular}

Notes: These data are for manufacturing enterprises. Sales figures are in billions of dollars. The IRS data are for controlled foreign corporations and their U.S.-incorporated parents. The BEA data are for parents located in the U.S. and affiliates located abroad; the affiliates include both majority-owned and minority-owned affiliates. See the text for the comparability of the two data sets.

Sources: The Internal Revenue Service and the Bureau of Economic Analysis. 
Table 13: Regression Estimates of Multinationals' Cost Function, Nine-Year Panel

\begin{tabular}{ccccccc}
\hline \hline Specification & $(\mathrm{S} 1)$ & $(\mathrm{S} 2)$ & $(\mathrm{S} 3)$ & $(\mathrm{S} 4)$ & $(\mathrm{S} 5)$ & $(\mathrm{S6})$ \\
\hline$\beta_{\mathrm{pa}}$ & -.135 & -.121 & -.058 & -.135 & -.169 & -.098 \\
standard error & .028 & .027 & .021 & .028 & .033 & .026 \\
$\eta_{\mathrm{pa}}$ & .045 & .063 & .113 & -.103 & -.139 & -.040 \\
$95 \%$ C.I. & $(-.03, .12)$ & $(-.01, .13)$ & $(.06, .17)$ & $(-.20,-.01)$ & $(-.25,-.03)$ & $(-.13, .05)$ \\
$\%$ C.I. which & $80 \%$ & $90 \%$ & $95 \%$ & $95 \%$ & $95 \%$ & $65 \%$ \\
excludes zero & & & & & & \\
$\eta_{\mathrm{ap}}$ & .161 & .227 & .500 & -.400 & -.530 & -.189 \\
$\eta_{\mathrm{aa}}$ & -.163 & .039 & -.463 & -.208 & -.085 & -.371 \\
$\eta_{\mathrm{pp}}$ & -.045 & -.063 & -.113 & -.209 & -.190 & -.256 \\
\# obs. & 276 & 276 & 276 & 280 & 280 & 282 \\
\hline
\end{tabular}

Notes: Specifications (S1) through (S6) are described in the text; each is a variation of a translog cost function for U.S. multinationals over the 1980's as given in equation (11'). The panel consists of the 32 BEA manufacturing industries over the nine census and survey years. Each specification contains a full set of industry dummies and time dummies and is estimated using Zellner's SURE technique. The subscripts "a" and "p" designate affiliate and parent, respectively. " $\beta$ pa" is the estimated coefficient on parent (affiliate) compensation rates in the affiliate (parent) cost-share equation. " $\eta_{\mathrm{pa}}$ " is the implied price elasticity of demand for parent labor with respect to affiliate compensation costs. "95\% C.I." is the $95 \%$ confidence interval corresponding to $\eta_{\mathrm{pa}}$ as calculated according to the formula given in Appendix B. "\% C.I. which excludes zero" is the approximate degree of confidence required to make the interval surrounding $\eta_{\mathrm{pa}}$ lie strictly on one side of zero. " $\eta_{\mathrm{ap}}$ " is the implied price elasticity of demand for affiliate labor with respect to parent compensation costs. " $\eta_{\mathrm{aa}}$ " is the own-price elasticity of demand for affiliate labor, and " $\eta_{\mathrm{pp}}$ " is the similar elasticity for parent labor. All elasticities are defined in (8) and calculated according to (12). "\# obs." is the number of observations.

Sources: The Bureau of Economic Analysis and Moody's Investor Service 
Table 14: Regression Estimates of Multinationals' Cost Function, Three-Year Panel

\begin{tabular}{ccccc}
\hline \hline Specification & $(\mathrm{Sp} 1)$ & $(\mathrm{Sp} 2)$ & $(\mathrm{Sp} 3)$ & $(\mathrm{Sp} 4)$ \\
\hline$\beta_{\mathrm{pa}}$ & -.159 & -.179 & -.160 & -.171 \\
standard error & .106 & .101 & .111 & .105 \\
$\eta_{\mathrm{pa}}$ & -.341 & -.395 & -.344 & -.374 \\
$95 \%$ C.I. & No & No & No & No \\
$\begin{array}{c}\text { excludes zero? } \\
\eta_{\mathrm{ap}}\end{array}$ & -1.38 & -1.60 & -1.39 & -1.51 \\
$\eta_{\mathrm{aa}}$ & -.076 & -.206 & -.239 & -.436 \\
$\eta_{\mathrm{pp}}$ & -.161 & .028 & -.222 & -.029 \\
\# obs. & 96 & 96 & 96 & 96 \\
\hline
\end{tabular}

Notes: Specifications ( $\mathrm{Sp} 1)$ through $(\mathrm{Sp} 4)$ are described in the text; each is a variation of a translog cost function for U.S. multinationals over the 1980's as given in equation (11'). The panel consists of the 32 BEA manufacturing industries over the three census years. Each specification contains a full set of industry dummies and time dummies and is estimated using Zellner's SURE technique. The subscripts "a" and " $p$ " designate affiliate and parent, respectively. " $\beta$ pa" is the estimated coefficient on parent (affiliate) compensation rates for production labor in the cost-share equation for affiliate (parent) production labor. " $\eta_{\mathrm{pa}}$ " is the implied price elasticity of demand for parent production labor with respect to affiliate production compensation costs. "95\% C.I. excludes zero?" designates whether or not the $95 \%$ confidence interval corresponding to $\eta_{\mathrm{pa}}$ (as calculated according to the formula given in Appendix B) lies strictly on one side of zero. " $\eta_{\mathrm{ap}}$ " is the implied price elasticity of demand for affiliate production labor with respect to parent production compensation costs. " $\eta_{\mathrm{aa}}$ " is the own-price elasticity of demand for affiliate production labor, and " $\eta_{\mathrm{pp}}$ " is the similar elasticity for parent production labor. All elasticities are defined in (8) and calculated according to (12). "\# obs." is the number of observations.

Sources: The Bureau of Economic Analysis 